\title{
Cultural Resources Survey of the Proposed Moore Park Athletic Complex, Plano, Collin County, Texas
}

Brett Lang

Melissa M. Green

Follow this and additional works at: https://scholarworks.sfasu.edu/ita

Part of the American Material Culture Commons, Archaeological Anthropology Commons, Environmental Studies Commons, Other American Studies Commons, Other Arts and Humanities Commons, Other History of Art, Architecture, and Archaeology Commons, and the United States History Commons

Tell us how this article helped you.

This Article is brought to you for free and open access by the Center for Regional Heritage Research at SFA ScholarWorks. It has been accepted for inclusion in Index of Texas Archaeology: Open Access Gray Literature from the Lone Star State by an authorized editor of SFA ScholarWorks. For more information, please contact cdsscholarworks@sfasu.edu. 
Cultural Resources Survey of the Proposed Moore Park Athletic Complex, Plano, Collin County, Texas

\section{Creative Commons License}

\section{(c) (1) (8)}

This work is licensed under a Creative Commons Attribution-NonCommercial 4.0 International License 


\section{Cultural Resources Survey of the Proposed Moore Park Athletic Complex, Plano, Collin County, Texas}

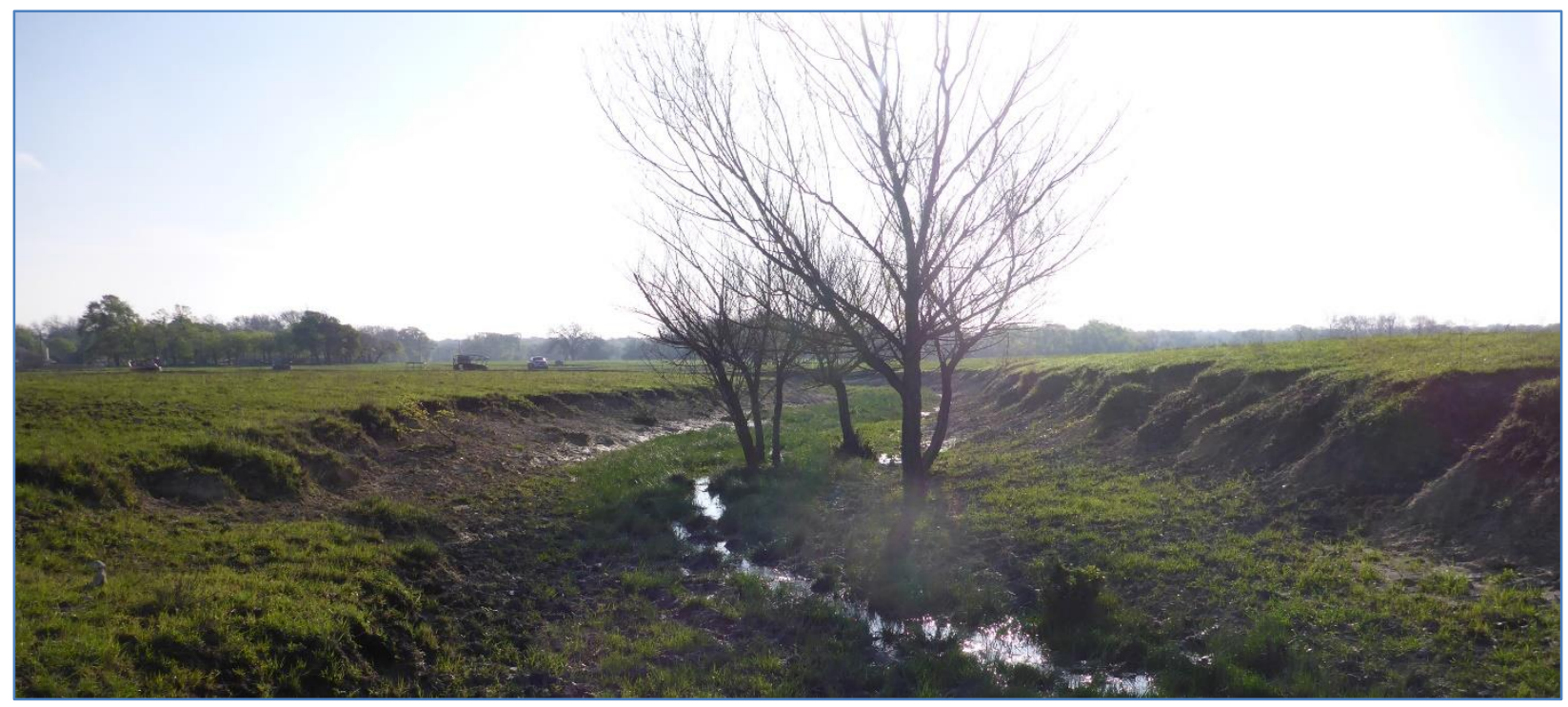

Prepared by:

Brett Lang (Project Archeologist)

Melissa M. Green (Principal Investigator)

Cox $\mid$ McLain Environmental Consulting, Inc.

600 E. John Carpenter Freeway, Suite 186

Irving, Texas 75062

Prepared for:

City of Plano

Parks and Recreation

5901 Los Rios Boulevard

Plano, Texas 75074

Under:

Texas Antiquities Permit 9334

Cox |McLain Environmental Consulting, Inc. Archeological Report 298

(CMEC-AR-298)

COX | McLAIN

Environmental Consulting

May 30, 2020. 
In March 2020, an intensive cultural resources survey of the proposed Moore Park athletic complex in Plano, Collin County, Texas was completed in order to inventory all cultural resources. The project parcel currently lies within an open field at the southwest corner of the intersection of Chaparral Road and Cottonwood Creek. It is bounded by Chaparral Road on the north, Cottonwood Creek to the east, Bright Star Way on the south, and Cloverhaven Way on the west in a densely residential developed area. A North Texas Municipal Water District building is located in the far northwestern corner near Cottonwood Creek. The archeological area of potential effects (APE) covers an area of approximately 103 acres (42 hectares).

Because the project is owned and funded by the City of Plano, a political subdivision of the State of Texas, the project is subject to the Antiquities Code of Texas (9 Texas Natural Resources Code [TNRC] 191), which requires consideration of effects on properties designated as - or eligible to be designated as-State Antiquity Landmarks (SALs), which includes archeological resources. The survey was carried out for the City of Plano, Parks and Recreation under Texas Antiquities Permit 9334 by Brett Lang (Project Archeologist) of Cox|McLain Environmental Consulting, Inc. (CMEC). Melissa M. Green was the Principal Investigator.

The parcel is situated on an upper terrace above Cottonwood Creek. From the western boundary, an unnamed tributary of Cottonwood Creek flows from the northwest corner to the southwest corner of the project parcel (as the terrace slopes southeastward) into Cottonwood Creek approximately 860 meters or 2821.5 feet away. Cottonwood Creek parallels the eastern boundary of the APE. Ground surfaces within the project area parcel were mostly covered in short, ankle-high prairie grasses used for active cattle grazing allowing for some limited visibility ranging from 20 to 50 percent. A densely wooded section was observed along the eastern boundary and along part of the tributary, allowing for 30 to 80 percent ground visibility. In all, 19 shovel test units were excavated judgmentally across the project area, of which none contained cultural materials.

All materials (notes, photographs, administrative documents, and other project data) generated from this work will be housed at the Center for Archeological Studies at Texas State University at San Marcos, where they will be made permanently available to future researchers per 13 Texas Administrative Code 26.16-17.

If any unanticipated cultural materials or deposits are found at any stage of clearing, preparation, or construction, the work should cease and Texas Historical Commission personnel should be notified immediately.

The Texas Historical Commission concurred with the findings and recommendations of this report on 8 May 2020. 


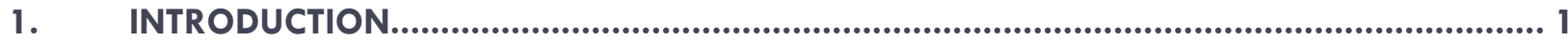

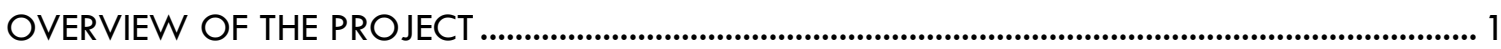

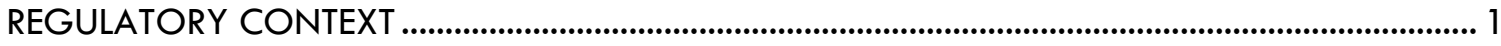

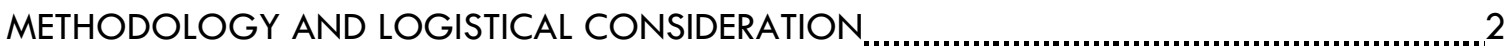

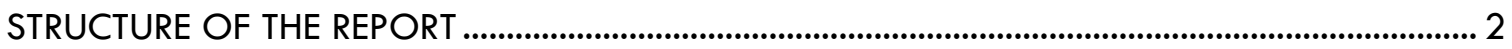

2. ENVIRONMENTAL AND CULTURAL CONTEXT ........................................................ 5

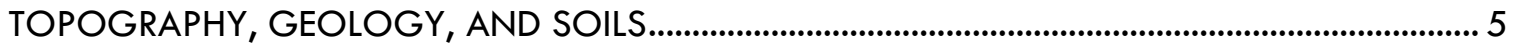

VEGETATION, PHYSIOGRAPHY, AND LAND USE......................................................................... 5

GENERAL ARCHEOLOGICAL CHRONOLOGY FOR NORTH-CENTRAL TEXAS................................. 5

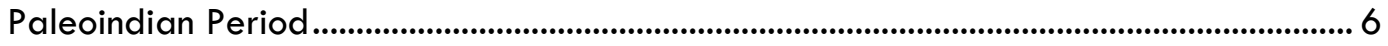

Archaic Period .............................................................................................................................. 6

Late Prehistoric Period........................................................................................................... 7

Protohistoric and Historic Period...................................................................................................... 7

PREVIOUS INVESTIGATIONS AND PREVIOUSLY IDENTIFIED RESOURCES..................................... 8

3. RESEARCH GOALS AND METHODS ................................................................ 11

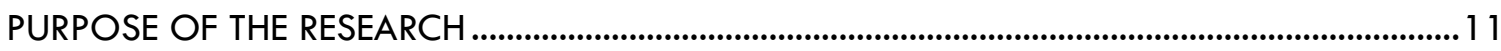

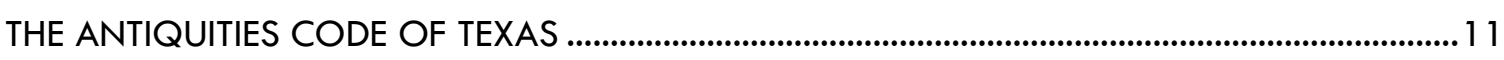

ARCHEOLOGICAL SURVEY METHODS AND PROTOCOLS............................................................. 12

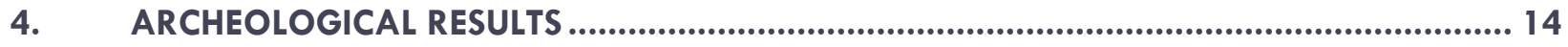

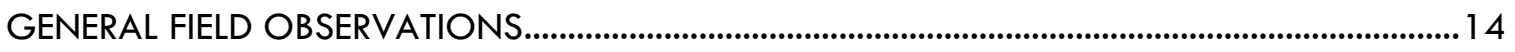

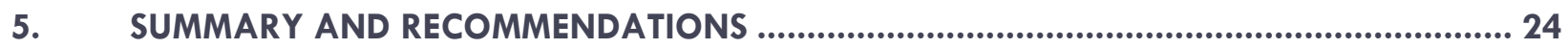

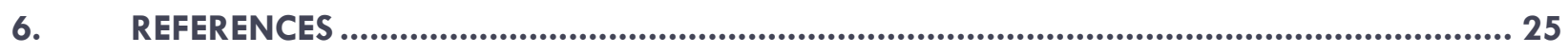

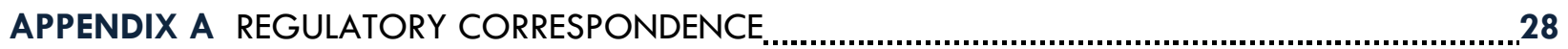




\section{List of Figures}

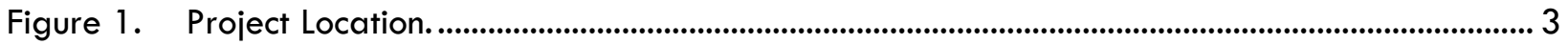

Figure 2. Location of Archeological APE ..................................................................................................... 4

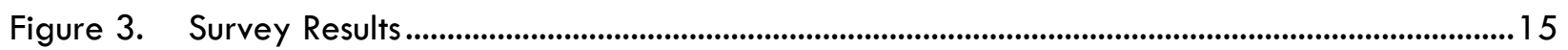

Figure 4. Cottonwood Creek at the eastern boundary of the APE; view north ....................................... 16

Figure 5. APE from the northwest corner showing active cattle grazing pasture; view east ................. 16

Figure 6. Project area from southwest corner towards Cloverhaven Way; view west............................ 17

Figure 7. Wooded area near the eastern end of the APE in an eroded area; view east ....................17

Figure 8. Increased ground visibility near ST BL9 the wooded section; view east................................... 18

Figure 9. Shallow tributary near ST BL4 showing limestone close to the surface; view west................. 18

Figure 10. View of wider and deeper tributary near ST BL10; view east................................................. 19

Figure 11. Shovel test BLI5 showing typical stratigraphy; view north and down ................................... 19

Figure 12. Disturbed berm parallel to Cloverhaven Way running north/south; view north....................21

Figure 13. Two-lane paved hike and bike path along eastern boundary; view south.............................22

Figure 14. NTMWD maintenance facility construction disturbance NE corner of APE; view

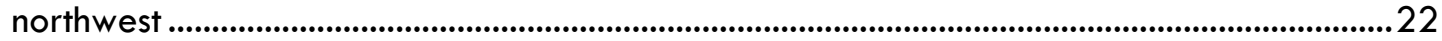

Figure 15. Sewer line disturbance at the northeast corner of $A P E ;$ view west............................................23

Figure 16. Sewer line corridor disturbance on west bank of Cottonwood Creek; view south................23

\section{List of Tables}

Table 1. Archeological Chronology for North Central Texas ....................................................................... 6

Table 2. Shovel Test Unit Excavation Results ............................................................................................20 


\section{INTRODUCTION}

\section{OVERVIEW OF THE PROJECT}

The City of Plano (the City) Parks and Recreation requested a cultural resources survey prior to the construction of an athletic complex at Moore Park. The athletic complex elements will include multipurpose playing fields, light masts, parking, access drives, trails, and screening berms. The greatest depth would be for the piers under the lighting masts, which will go down to bedrock. For the remainder of the project the excavation depth will not exceed 24 inches (in) or 61 centimeters $(\mathrm{cm})$ below ground surface. The project is located on the 103-acre (ac), or 42-hectare (ha) plot in northeast Plano in southwest Collin County, Texas (Figure 1); this 103-acre plot is the archeological area of potential effects (APE).

On March 26, 2020, Brett M. Lang (Project Archeologist) of Cox|McLain Environmental Consulting, Inc. (CMEC) conducted an intensive archeological survey augmented with judgmental shovel testing of the 103-ac (42-ha) tract. The project parcel currently lies within an open field in a densely residential developed area at the southwest corner of the intersection of Chaparral Road and Cottonwood Creek. It is bounded by Chaparral Road to the north, Cottonwood Creek to the east, Bright Star Way to the south, and Cloverhaven Way to the west. A North Texas Municipal Water District building is located in the far northwestern corner, near Cottonwood Creek. The parcel is situated on an upper terrace above Cottonwood Creek. From the western boundary, a tributary of Cottonwood Creek flows from the northwest corner to the southwest corner of the APE (as the terrace slopes southeastward) into Cottonwood Creek approximately 860 meters ( $\mathrm{m} ; 2821.5$ feet [ft]) away (Figure 2). Cottonwood Creek parallels the eastern boundary of the APE.

\section{REGULATORY CONTEXT}

Because the project is owned and funded by the City of Plano, a political subdivision of the State of Texas, the project is subject to the Antiquities Code of Texas (9 Texas Natural Resources Code [TNRC] 191), which requires consideration of effects on properties designated as - or eligible to be designated as-State Antiquity Landmarks (SALs), which includes archeological resources. The purpose of the investigation described in this document was to conduct an intensive survey for archeological resources (Category 2 under 13 Texas Administrative Code [TAC] 26.20), including both previously unknown resources and previously documented resources, if any, within the 103-ac (42-ha) project area. If previously unidentified significant resources had been identified during the survey, they would have been evaluated for inclusion in the National Register of Historic Places (NRHP; 36 Code of Federal Regulations [CFR] 60) or for listing as a SAL (13 TAC 26.12). All materials generated from this work will be permanently housed at the Center for Archeological Studies (CAS) at Texas State University at San Marcos per TAC 26.16 and 26.17. 
The project has a low probability of encountering human burials. If burials had been found, the City Parks and Recreation Department and Texas Historical Commission (THC) would have been notified, and all requirements of 8 Texas Health and Safety Code (THSC) 711 followed.

\section{METHODOLOGICAL AND LOGISTICAL CONSIDERATIONS}

Nineteen shovel test units (STs) were excavated within the project boundaries. All shovel tests were placed based on guidelines established by the Council of Texas Archeologists (CTA) and approved by the THC. The shovel test locations were selected based on observed disturbance levels and ground surface visibility. All shovel tests were excavated in natural levels to subsoil or $50 \mathrm{~cm}$ (19.6 in), whichever was encountered first. Excavated matrix was screened through $0.635-\mathrm{cm}(0.25-\mathrm{in})$ hardware cloth as allowed by moisture and clay content and deposits were described using conventional texture classifications and Munsell color designations. Any deviations from THC and CTA standards are explicitly justified in the Results section of this report.

\section{STRUCTURE OF THE REPORT}

Following this introduction, Chapter 2 presents environmental parameters, a brief cultural context, and a summary of previous archeological research near the APE. Chapter 3 discusses research goals, relevant methods, and the underlying regulatory considerations. Chapter 4 presents the results of the survey and analysis of historic resources. Chapter 5 summarizes these investigations and offers recommendations, and references are in Chapter 6. 


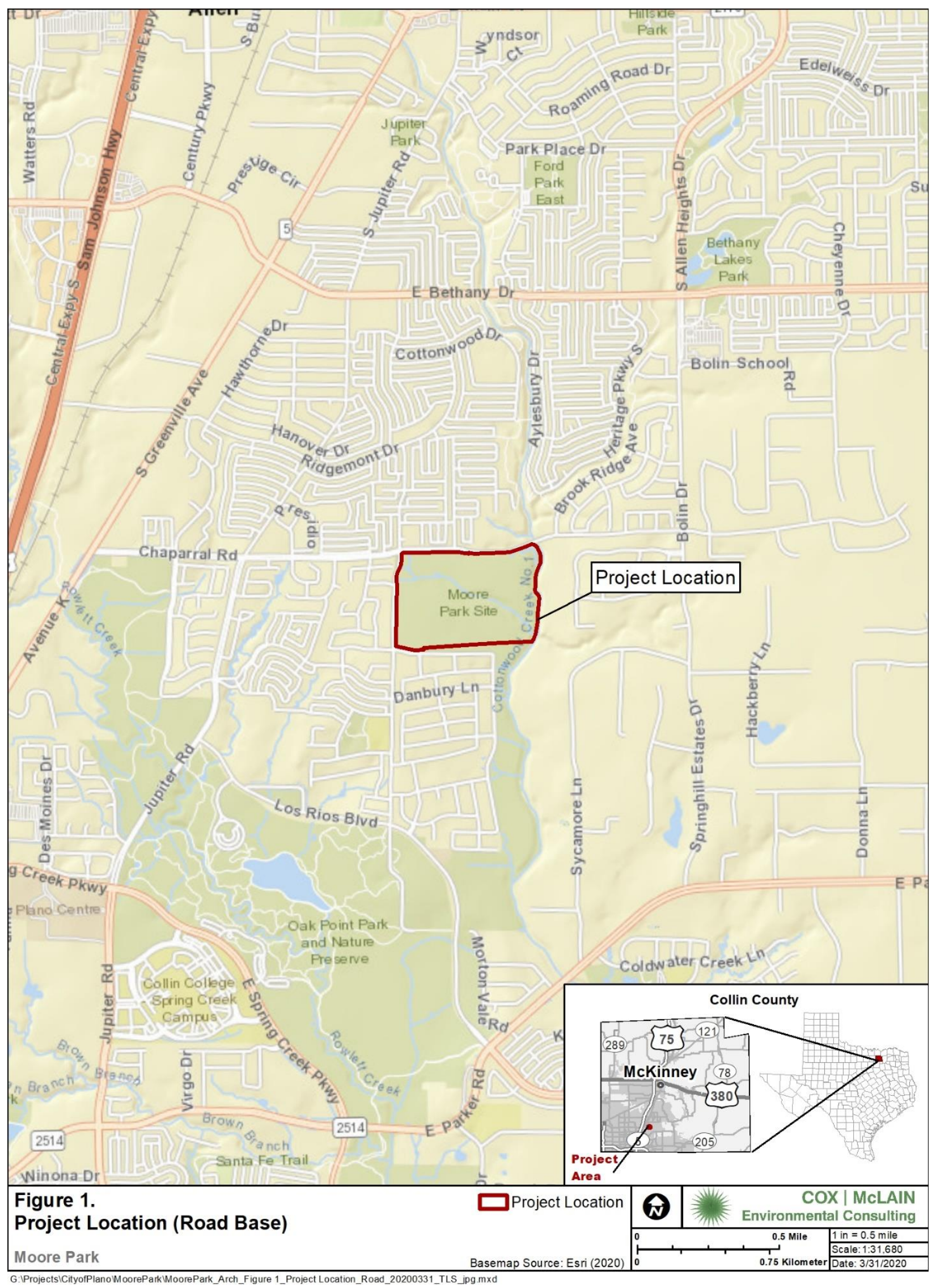




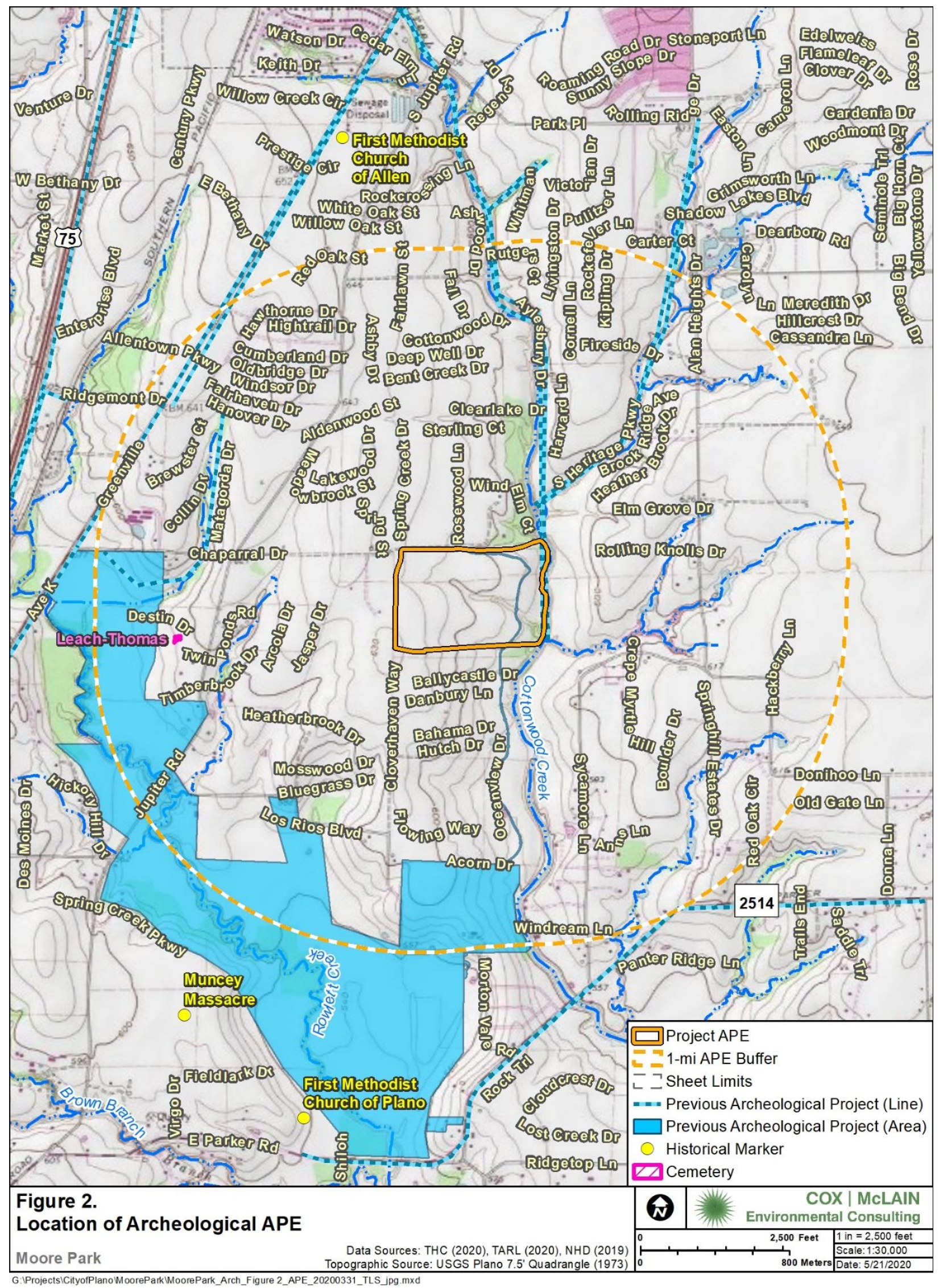




\section{ENVIRONMENTAL AND CULTURAL CONTEXT}

\section{TOPOGRAPHY, GEOLOGY, AND SOILS}

The APE is the 103-ac (42-ha) park located at approximately 567 to $633 \mathrm{ft}$ (173 to $193 \mathrm{~m}$ ) above mean sea level. The project is located in the Blackland Prairie ecoregion and land use is parkland (Griffith et al. 2010). The parcel is situated on a nearly square parcel on the western, upper terrace above Cottonwood Creek. It is underlain by Late Cretaceous-age Austin Chalk, which is comprised of chalk with some interbeds and partings of calcareous clay (U.S. Geological Survey [USGS] 2020).

There are four mapped soils in the project parcel. Eroded Houston Black clay on 2 to 4 percent slopes is found over much of the northern and western portions of the parcel. Moderately eroded Austin silty clay on 2 to 5 percent slopes soils is mapped around the southern end of the parcel, along the upper end of the Cottonwood Creek tributary that cuts across the parcel, and along the outer edge of the Houston Black clay on 1 to 3 percent slopes that is mapped along the lower portion of the tributary. The last soil mapped within the APE is occasionally flooded Trinity clay on 0 to 1 percent slopes, which is located along Cottonwood Creek. Houston Black soils have a $20-\mathrm{cm}$-thick A horizon over a series of Bkss horizons extending to a depth of $264 \mathrm{~cm}$ below surface (cmbs) and are found on interfluves and side slopes on upland ridges. Austin soils have $A p$ and $A$ horizons extending to depths of 15 and $41 \mathrm{~cm}$ underlain by $B w, B k$, and $C$ horizons extending 56,74, and $144 \mathrm{cmbs}$, and are found on erosional uplands. Trinity soils occur on floodplains and feature an Ap and A horizon at depths similar to the Austin soils, underlain by a series of Bkss horizons to a depth of $191 \mathrm{cmbs}$ (Soil Survey Staff 2020).

\section{VEGETATION, PHYSIOGRAPHY, AND LAND USE}

The APE is currently parkland dominated by short ankle- to shin-high prairie grasses and a small section of trees near the northeast corner. Based on field observations, the project parcel continues to be used for grazing of cattle. The slope of the project area and terracing in the past make it unlikely that the fields were used for any row crops for any length of time. Average annual precipitation in this region is reported to be between 38 and 42 inches (in; 96.5 and $106.6 \mathrm{~cm}$ ) from 1981 to 2010 (Spatial Climate Analysis Service [SCAS] 2000).

\section{GENERAL ARCHEOLOGICAL CHRONOLOGY FOR NORTH-CENTRAL TEXAS}

The APE lies within the western part of the north-central Texas archeological region (Perttula 2004). The standard cultural chronology for the region has changed little in the last two decades; thus, the periods and date ranges established by Peter and McGregor (1988), Prikryl (1990), and Yates and Ferring (1986) still apply (Table 1). The general prehistoric framework for north-central Texas is similar to that used in other areas of Texas, and indeed throughout much of North America, with the first unequivocal human occupations occurring approximately 11,500 radiocarbon years before present (BP), or 
approximately 13,000 calendar years ago, and most of the prehistoric record is contained within a long Archaic period lasting nearly 8,000 years.

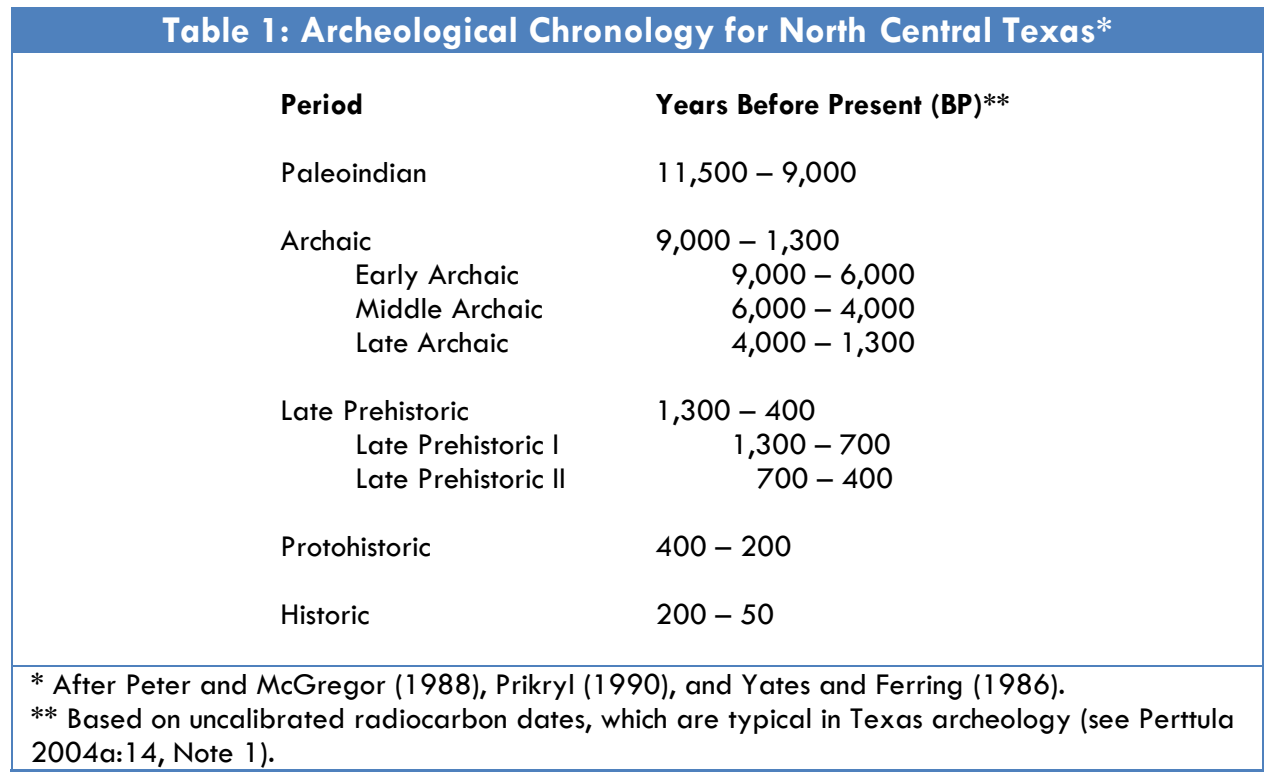

\section{Paleoindian Period}

The Paleoindian occupation is the least known period in the prehistory of north-central Texas, due primarily to three factors: the light population density of Paleoindian peoples, the great age of the occupation (up to 13,000 calendar years), and taphonomic factors such as severe erosion and deep sedimentation, depending on location (Ferring 1989, 2001; Holliday 2004). Although initially seen as narrowly specialized big-game hunters, Paleoindian groups such as Clovis are being reevaluated in light of recent discoveries such as the Aubrey site north of Dallas-Fort Worth. At Aubrey, investigators found evidence of a more balanced, flexible subsistence strategy, with remains of big game such as bison and mammoth, but also fish, birds, and other small game (Ferring 2001). Generally, Paleoindian people are thought to have been more mobile than subsequent populations, utilizing lithic and other resources from broad geographic areas.

\section{Archaic Period}

Usually divided into three (more or less) equal parts, the Archaic Period encompasses the bulk of northcentral Texas prehistory. The Archaic record is clouded by mixed deposits (Hofman et al. 1989; Prikryl 1990 ) and possible large-scale erosion in the middle of the period (as has been documented farther to the west by Blum and colleagues [1992]). Still, the available data show that Archaic peoples were more likely than their predecessors to make projectile points and other stone tools out of local raw materials, potentially indicating more spatially restricted territories and/or subsistence areas, perhaps reflecting seasonal rounds through a specific series of resource-gathering zones (Ferring and Yates 1997; Peter and McGregor 1988). Generally, population is thought to have increased throughout the Archaic Period, perhaps in response to stabilizing climatic conditions. 


\section{Late Prehistoric Period}

The Late Prehistoric Period is defined technologically, with the beginning of the period typically marked by the appearance of arrow points and ceramics. Aside from the addition of these extremely important technologies, the overall trajectory of subsistence lifeways in the Late Prehistoric is usually thought to represent a continuation of trends seen in the later part of the Archaic, with even more dramatic focus on very local resources and broad-spectrum foraging (Ferring and Yates 1997). In the latter part of the period (Late Prehistoric II), the picture shifts, with ceramic and lithic evidence indicating links to Plains populations to the north and west (Prikryl 1990).

\section{Protohistoric and Historic Period}

The beginning of the Protohistoric Period is marked by the first appearance of Europeans in Texas: the Spanish explorers, priests, and speculators who began moving into the state from colonies to the south and west in the sixteenth and seventeenth centuries. Although technically historic (i.e., characterized by the use of writing), this earlier phase is often separated from the more-formally designated Historic Period due to the relative infrequency of direct Spanish incursions into north-central Texas, in contrast to the high-profile, early Spanish occupations in south and south-central Texas (Campbell 2003). Even without the missions, military outposts, and other facilities characteristic of the Spanish presence to the south, the effects of trade, disease, and other factors on native populations were still dramatic, and indigenous groups of the Protohistoric Period are little known apart from sporadic finds of European trade goods at native sites (Stephenson 1970).

The last two centuries are considered the Historic Period. In brief, the landscape and material culture of north-central Texas during this time are characterized by the overwhelming dominance of Europeanderived populations and the expansion of railroads, the discovery and exploitation of petroleum resources, the supplanting of small tenant farming by mechanized agriculture and urban sprawl, and various waves of commercial and industrial development, the most recent example being the rise of the service and information economies (Campbell 2003).

Euro-American settlement of this area of North Central Texas began in the early 1840s with the establishment of Peters Colony. William S. Peter and a group of other investors from London, England, and Louisville, Kentucky, formed Peters Colony through a contract with the President of Texas, Mirabeau Lamar; the contract was authorized by the Texas Congress on January 4, 1841 (Texas General Land Office n.d.). Although there were numerous legal battles over ownership of the land during the colony's early years, 2,205 families ultimately came to Texas to settle in Peters Colony and 879,920 ac of land were distributed to them ("Peters Colony Records" n.d.; Wade 2010). Each family that settled in Peters Colony received 640 ac and single men received 320 ac (Farmer 2011:16).

After Texas became the 28th state of the United States of America, Peters Colony was organized into four different counties (Farmer 2011:14). Collin County was established in April of 1846 and named for Collin McKinney, who was a signer of the Texas Declaration of Independence (Farmer 201 1:15; 
Minor 2010). By this time, the county was home to 150 of the Peters Colony families (Wade 2010). The families found the soils of the upper Blackland prairie to be good for raising corn, wheat, sorghum, and hay with a long growing season of almost 230 days. The prairie also provided good pasture land for stock animals (Farmer 2011:14-15).

The early settlement and economic trends in Collin County dramatically changed in the 1870s with the arrival of the railroad in the region. The Houston and Texas Central Railroad arrived in Collin County on October 2, 1872, establishing a connection with ports in Houston and Galveston and spurring a 50year agriculture-based economic boom for the county (Farmer 2011:39). By the end of the nineteenth century, six railroads crossed the county, opening even more markets to the region's farmers. Agricultural production in Collin County grew rapidly in the last three decades of the nineteenth century. By the turn of the twentieth century, there were 903 farms valued at just over $\$ 3$ million, and Collin County ranked $14^{\text {th }}$ in the United States for agricultural production (Minor 2010; Farmer 2011:56). Production continued to increase, and by 1920 the farms numbered 6,001 with an estimated value over $\$ 84$ million. Corn, cotton, and wheat were the primary crops (Minor 2010). Stock raising, including cattle, horses, and mules, was also a substantial economic driver for some Collin County farmers (Quinn 1995:1B). One aspect of the agriculture-based economic prosperity was a corresponding increase in land prices; over 68 percent of the county's farmers were tenant farmers by 1920 (Farmer 201 1:55).

Despite the economic prosperity of the late nineteenth and early twentieth centuries in Collin County, the region was hit by the effects of the Great Depression of the 1930s and early 1940s, as well as by the results of farming mechanization that decreased the need for human labor in agricultural production (Minor 2010). During the mid-twentieth century, the county experienced a decrease in population, a 22 percent drop in the number of farms, and high unemployment.

Up to the 1970s, Collin County remained primarily a farming-based area. However, this began changing almost overnight as residents and businesses moved from Dallas to the surrounding communities. Major employers, such as Dr. Pepper, Snapple, Ericsson, Frito-Lay, and AT\&T Wireless, moved to Collin County (Farmer 2011:68). According to Minor (2010), 25 percent of the county's population was employed in manufacturing and 23 percent in wholesale and retail trade by 1980 . Plano became the county's fastest growing city, quickly surpassing the county seat of McKinney, with an increase in population from 3,695 in 1960 to 72,331 in 1980. To accommodate Plano's rapid growth, the city limits were increased.

\section{PREVIOUS INVESTIGATIONS AND PREVIOUSLY IDENTIFIED RESOURCES}

A search of the Texas Archeological Sites Atlas (Atlas), maintained by THC and Texas Archeological Research Laboratory (TARL), was conducted in order to identify archeological sites, historical markers (Recorded Texas Historic Landmarks), properties or districts listed in the NRHP, SALs, cemeteries, and previously conducted cultural resource investigations. The survey information available on the Atlas is, 
however, somewhat limited to investigations conducted under the Antiquities Code of Texas, and may not include all projects (i.e., projects conducted under Section 106 only). A 1-mi (1.6-km) study area around the project APE was also examined to understand what the potential for archeological sites and types of sites might exist in this project.

According to the Atlas search, the parcel has not been previously surveyed for cultural resources. There are four previously recorded resources and five previous cultural resources surveys within $1 \mathrm{mi}$ of the APE. The four known resources are archeological sites 41 COL88, 41 COL89 (Leach-Thomas Cemetery), $41 \mathrm{COL} 151$, and $41 \mathrm{COL} 215$. The surveys in the area include two paralleling surveys (1978 and 1992) running along the east side of Cottonwood Creek and northeast side of an unnamed tributary to Cottonwood Creek; 1989 and 1992 surveys along Greenville Avenue; a 1992 survey along Rowlett Creek conducted by the Texas Water Development Board (TWDB) for the City of Allen; a 2009 areal survey of the Oak Park Point Park and Nature Preserve for the City of Plano Parks and Recreation Department conducted by AR Consultants, Inc.; the 2017 Cottonwood Creek Trail Extension survey conducted for TxDOT by Integrated Environmental Solutions, LLC (located within the project parcel); and the 2018 survey for a new maintenance facility in the northeast corner of Oak Point Park for the Parks and Recreation Department and revisit of site 41COL88 conducted by Cox|McLain Environmental Consulting (CMEC) in 2018 (THC 2020).

Archeological site 41 COL88 is recorded as a historic-age farmstead within the boundaries of the Oak Point Park. It was originally recorded in 1992 during the TWDB survey that extended into what is now Oak Point Park and Nature Preserve. The site was revisited in 2018 during the CMEC survey for the park's new maintenance facility. The residential portion of the site was found to be completely destroyed by recent residential development and Chaparral Road with only a small portion of the yard left in the park. Evidence of an earthen berm, a shallow ditch, and some fence lines was all that remained during the revisit, and THC determined the site ineligible in January of 2018. Site 41COL89, also recorded during the 1992 TWDB survey, is the trinomial given to the Leach-Thomas Cemetery. According to the site form, local folklore has it that "members of Jeremiah Muncy family and several neighbors were interred here following their deaths in the final 'Indian massacre' in what is now Collin County." This has been debated in that they are actually believed to be buried at their homesite on a low terrace on the west side of Rowlett Creek, 400 m (1312 ft) upstream from the Jupiter Road crossing (Jurgens 1992). The Find A Grave website notes that the earliest legible headstone is that of William Joseph Perrin, who was interred in 1858 (Tipton 2020).

Sites 41 COL151 and 41COL215 are both historic-age sites, the Cottonwood School and an early 20th century residence, respectively. The Cottonwood School was an 1800s one-room schoolhouse. Although ground-truthed with negative results at the time of its recording in 2001, its location is based on early school records from the Post Office Museum in McKinney, oral accounts, and a 1930 map. Site 41COL151, a small domestic scatter (whiteware and porcelain sherds) found during a transmission survey conducted by Geo-Marine, Inc. in 2010 (not shown on Atlas), was identified. The site location was observed on the 1930 USDA Collin County soil survey map along with a bridge and road but none 
of these features were noted on the 1953 Army Map Service aerial photographs of the area (Goodmaster 2010; THC 2020).

A review of available historic aerials and topographic maps on Google Earth ${ }^{\mathrm{TM}}$ and the Nationwide Environmental Title Research (NETR) website was also undertaken to determine how the parcel had been utilized over time. According to the earliest topographic map of the area (1961, 1:24,000 scale), the parcel was undeveloped and the portion of Chaparral Road fronting it was illustrated as a two-track road that turned north near the center of the parcel and ended at a farmstead approximately $252 \mathrm{~m}$ $(826 \mathrm{ft}$ ) to the north. By the 1969 map, two additional structures have been built nearer the creek, with one of these in the northeast corner of the project parcel and the other north of the project parcel. No significant changes are noted on subsequent topographic maps until 2013 when the parcel is complete surrounded by development (NETR 2020).

Historic aerials reviewed include 1968, 1981, 1995, 2001, 2004, 2008, 2010, 2012, 2014, and 2016. The 1968 image shows the parcel in agricultural fields, terraced below the tributary and mowed pasture north of the tributary. On the earliest aerial available (1968), Chaparral Road mirrors what was illustrated on the 1961 topographic map, and the project parcel is in terraced agricultural fields south of the tributary and mowed pasture north of the tributary. By the 1995 imagery, a structure has been built in the northeast corner of the parcel, very near Cottonwood Creek, with a two-track road to it from the end of Chaparral near the center of the parcel; the residential subdivision on the north side of Chaparral is under construction at this time. On the 2004 imagery, Cloverhaven Way and the subdivision on its west side is under construction. Construction of Bright Star Way and the residential subdivision south of it along the southern boundary of the parcel is partially underway on the 2008 imagery. By 2010, construction for extending Chaparral Road to the east and across Cottonwood Creek is underway, as well as disturbances along the south side of the road to structure in the northeast corner of the parcel. In addition, construction of Bright Star Way on the south side of the APE is underway with it shown as completed by the 2012 image (Google Earth Pro ${ }^{T M}$ 2020; NETR 2020). No other significant changes are observed on subsequent imagery. 


\section{RESEARCH GOALS AND METHODS}

\section{PURPOSE OF THE RESEARCH}

The present study was carried out to accomplish two major goals:

1. Identify all historic and prehistoric archeological resources located within the APE defined in Chapter 1.

2. Make recommendations for further research concerning any identified resources based on the NRHP/SAL evaluation criteria and guidance on methodology and ethics from the THC and the CTA.

\section{THE ANTIQUITIES CODE OF TEXAS}

Because the project is currently owned and funded by the City of Plano, a political subdivision of the State of Texas, the project is subject to the Antiquities Code of Texas (9 TNRC 191), which requires consideration of effects on properties designated as-or eligible to be designated as-SALs, which are defined as:

... sites, objects, buildings, structures and historic shipwrecks, and locations of historical, archeological, educational, or scientific interest including, but not limited to, prehistoric American Indian or aboriginal campsites, dwellings, and habitation sites, aboriginal paintings, petroglyphs, and other marks or carvings on rock or elsewhere which pertain to early American Indian or other archeological sites of every character, treasure imbedded in the earth, sunken or abandoned ships and wrecks of the sea or any part of their contents, maps, records, documents, books, artifacts, and implements of culture in any way related to the inhabitants, prehistory, history, government, or culture in, on, or under any of the lands of the State of Texas, including the tidelands, submerged land, and the bed of the sea within the jurisdiction of the State of Texas (13 TAC 26.2).

Rules of practice and procedure for the evaluation of cultural resources as SALs, which is explicitly referenced at the state level, are detailed in 13 TAC 26. An archeological site identified on lands owned or controlled by the State of Texas may be of sufficient significance to allow designation as a SAL if at least one of the following criteria applies:

1. the site has the potential to contribute to a better understanding of the prehistory and/or history of Texas by the addition of new and important information;

2. the site's archeological deposits and the artifacts within the site are preserved and intact, thereby supporting the research potential or preservation interests of the site;

3. the site possesses unique or rare attributes concerning Texas prehistory and/or history;

4. the study of the site offers the opportunity to test theories and methods of preservation, thereby contributing to new scientific knowledge; or

5. the high likelihood that vandalism and relic collecting has occurred or could occur, and official landmark designation is needed to insure [sic] maximum legal protection, or alternatively further 
investigations are needed to mitigate the effects of vandalism and relic collecting when the site cannot be protected (13 TAC 26.10).

For archeological resources, the state-level process requires securing and maintaining a valid Texas Antiquities Permit from the THC, the lead state agency for Antiquities Code compliance. This permit must be maintained throughout all stages of investigation, analysis, and reporting.

Buildings, structures, cultural landscapes, and non-archeological sites, objects, and districts may also be designated as SALs, provided that the following conditions are met:

1. The property fits within at least one of the following criteria:

(A) the property is associated with events that have made a significant contribution to the broad patterns of our history, including importance to a particular cultural or ethnic group;

(B) the property is associated with the lives of persons significant in our past;

(C) the property embodies the distinctive characteristics of a type, period, or method of construction, represents the work of a master, possesses high artistic values, or represents a significant and distinguishable entity whose components may lack individual distinction;

(D) the property has yielded, or may be likely to yield, information important in Texas culture or history;

2. The property retains integrity at the time of the nomination, as determined by the executive director of the commission; and

3. For buildings and structures only, the property must be listed in the NRHP, either individually, or as a contributing property within a historic district. Contributing status may be determined by the Keeper of the National Register or the executive director of the commission.

\section{ARCHEOLOGICAL SURVEY METHODS AND PROTOCOLS}

With the goals and guidelines above in mind, CMEC personnel conducted an intensive survey of the APE per category 6 under 13 TAC 26.15 and using the definitions in 13 TAC 26.3. Field methods and strategies complied with the requirements of relevant subsections of 13 TAC 26, as elaborated by the THC and the Council of Texas Archeologists (CTA).

CMEC archeologists conducted an intensive survey level, consisting of pedestrian examination supplemented by judgmental shovel testing. As most of the parcel was in in an upland setting and previously in agricultural field, most of the shovel testing was concentrated near the tributary to and along Cottonwood Creek. CMEC anticipated the excavation of approximately 20 shovel test units; 19 were excavated. The 19 shovel tests were excavated in natural levels to subsoil or $50 \mathrm{~cm}(19.6 \mathrm{in})$, whichever was encountered first. Excavated matrix was screened through $0.635-\mathrm{cm}(0.25$-in) hardware cloth as allowed by moisture and clay content, which could have required that the removed sediment be crumbled/sorted by hand, trowel, and/or shovel point. Deposits were described using conventional texture classifications and Munsell color designations. Any artifacts encountered would have been 
counted, photographed, and described in the field before being returned to their shovel test unit or surface locations. If an archeological site had been identified and recorded, a Texas Archeological Site Form would have been prepared. Detailed notes and photographs were taken of all shovel tests, field conditions, and all previous impacts throughout the survey area. Deviations from THC and CTA standards would have been explicitly justified.

The project had a low probability of encountering human burials, however, if burials had been found, the City Parks and Recreation Department and THC would have been notified, and all requirements of 8 THSC 711 followed. 


\section{ARCHEOLOGICAL RESULTS}

\section{GENERAL FIELD OBSERVATIONS}

On March 26, 2020, CMEC personnel conducted an intensive survey of the 103-ac (42-ha) project APE (Figure 3). The parcel is situated on an upper terrace above Cottonwood Creek. From the western boundary, a tributary of Cottonwood Creek flows from the northwest corner to the southeast corner of the parcel (as the parcel slopes southeastward) into Cottonwood Creek approximately $860 \mathrm{~m} \mathrm{(2821.5}$ $\mathrm{ft}$ ) away. Cottonwood Creek parallels the eastern boundary of the project APE and the overall project area is surrounded by residential development to the north, east, south, and west. The highest point is along the western boundary in an open field used for active cattle grazing and parallels Cloverhaven Way. The ground slopes to the southeast towards the eastern boundary terminating at the western bank of Cottonwood Creek (Figure 4). Within the cattle grazing land concentrated on the western half of the parcel, ground visibility ranged from 20 to 50 percent with ankle- to shin-high Johnson grass and other prairie grasses the most common type of vegetation observed at the northwest and southwest corners (Figures 5 and 6). At the eastern end of the project parcel, the tributary of Cottonwood Creek flows towards the southeast in a wooded environment with 30 to 80 percent ground visibility observed. Vegetation in the wooded sections included red oaks, cedars, elms, honey locust trees, along with green briar and other unidentified plants and tree species (Figure 7 and 8).

Shovel testing was concentrated on the higher probability sections along the north and south banks of the tributary flowing into Cottonwood Creek and the west bank of Cottonwood Creek. The remaining areas were pedestrian surveyed with minimal shovel testing conducted as archeological potential was considered low to none due to the upland setting and previous agricultural use. A total of 19 STs were excavated, with 12 along the tributary and 5 on the west bank of Cottonwood Creek (see Figure 3). The shovel tests along the tributary demonstrated similar results with clay and mottled clay subsoil extending to 40 to $50 \mathrm{cmbs}$. The exception were the STs closer to the western boundary, which exhibited limestone bedrock or gravels near the surface and where the tributary channel is shallow (Figure 9). As the tributary continued southeast, the limestone was not evident, and the channel became deeper, wider, and more eroded (Figure 10). The remaining STs adjacent to the tributary, along with BL1 and BL16 at the northwest and southwest corners, were composed of 10YR2/1, 10YR3/2, or 10YR4/2 clay extending to $50 \mathrm{cmbs}$ (Figure 11 ). Shovel tests excavated along the west bank of Cottonwood Creek north of the confluence of the two drainages (BL17, BL18 and BL19) demonstrated similar results as those for the tributary with clay extending to $50 \mathrm{cmbs}$. The exceptions were the two STs south of the confluence (BL1 land BL 12), where 10YR2/1 sandy clay loam extended to $25 \mathrm{cmbs}$ before clay was encountered. No cultural material was observed on the surface or in any of the 19 shovel tests, and a complete description is found in Table 2. 


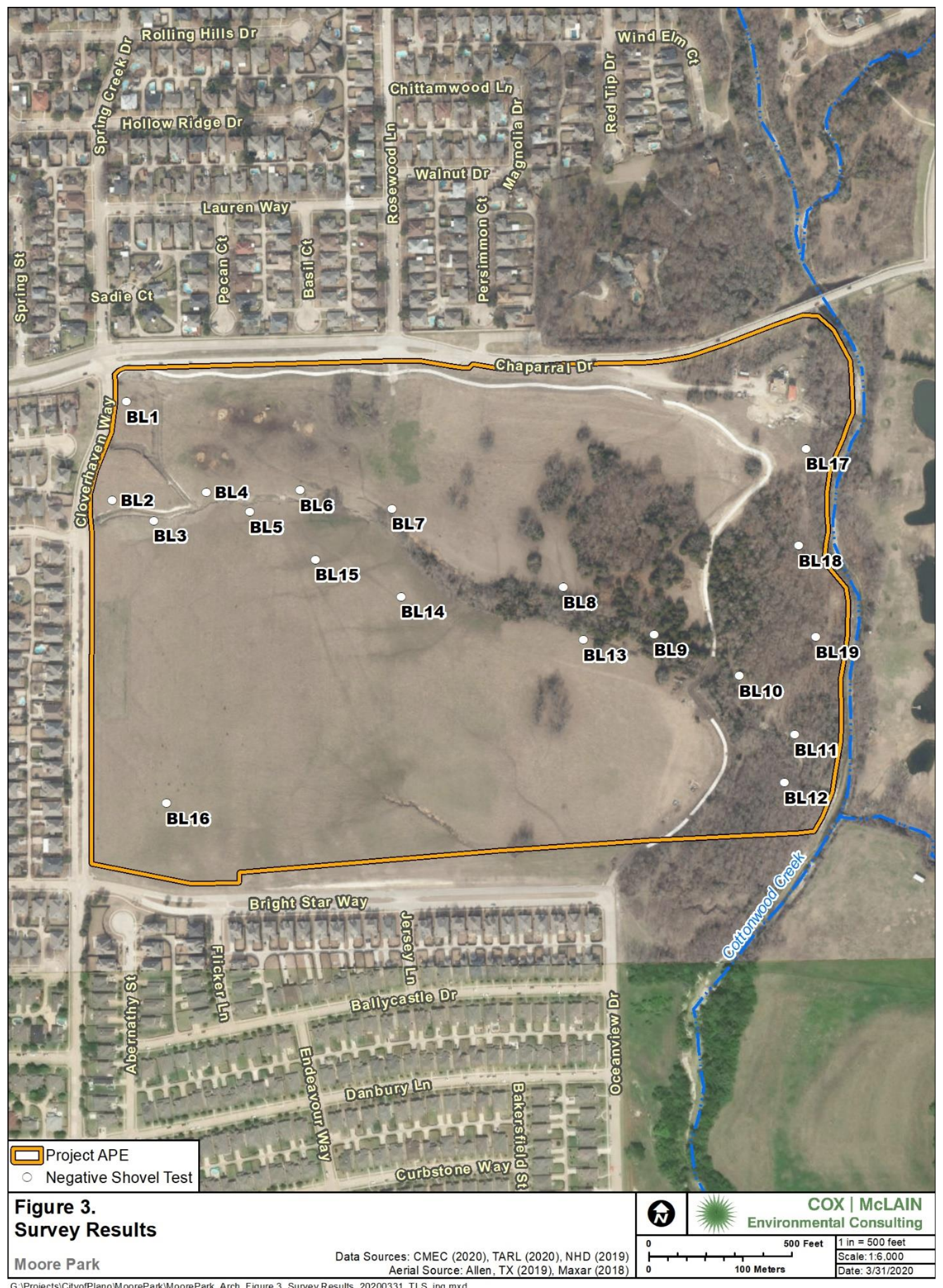

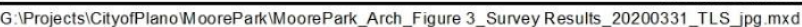




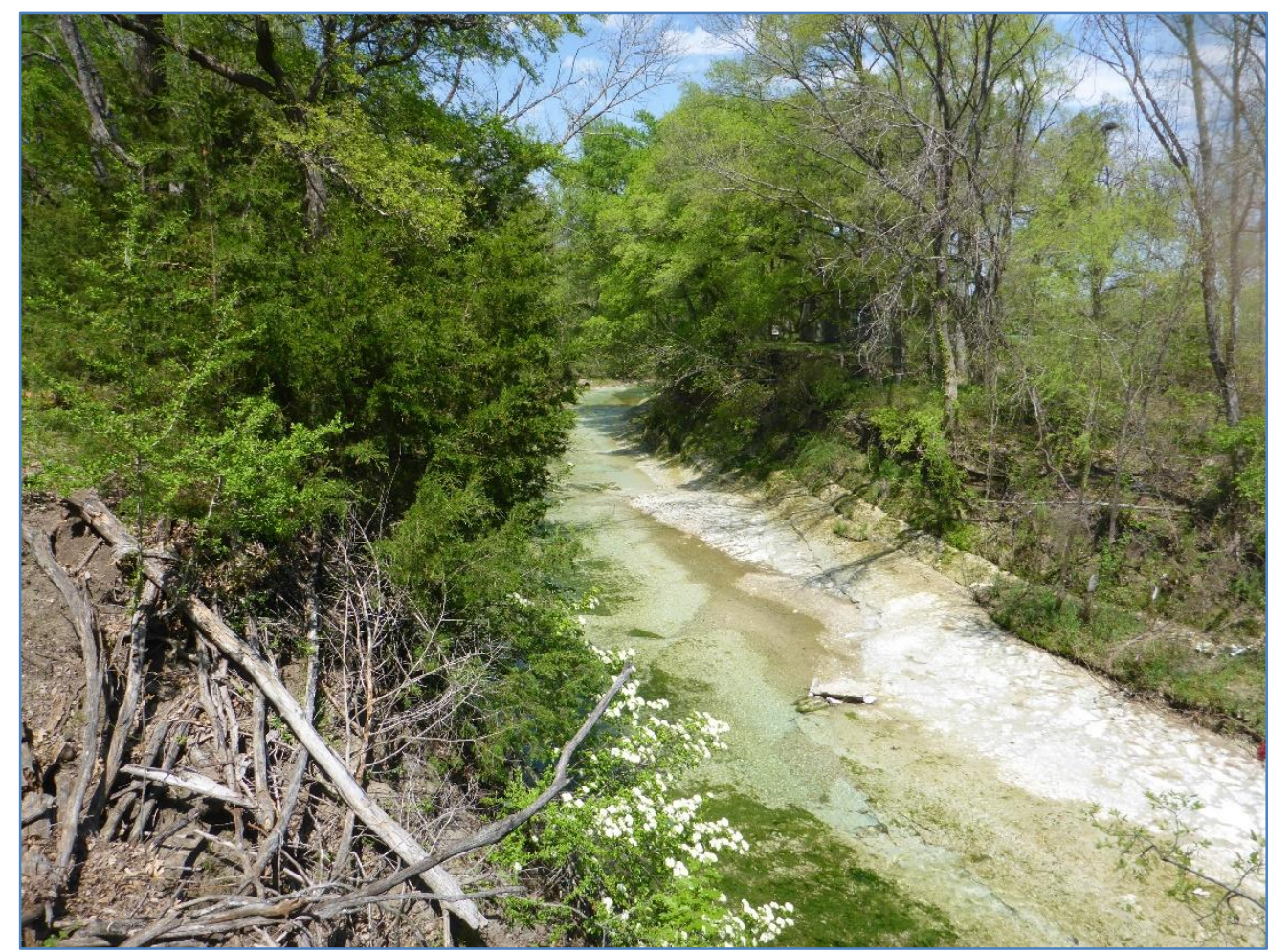

Figure 4. Cottonwood Creek at the eastern boundary of the APE; view north.

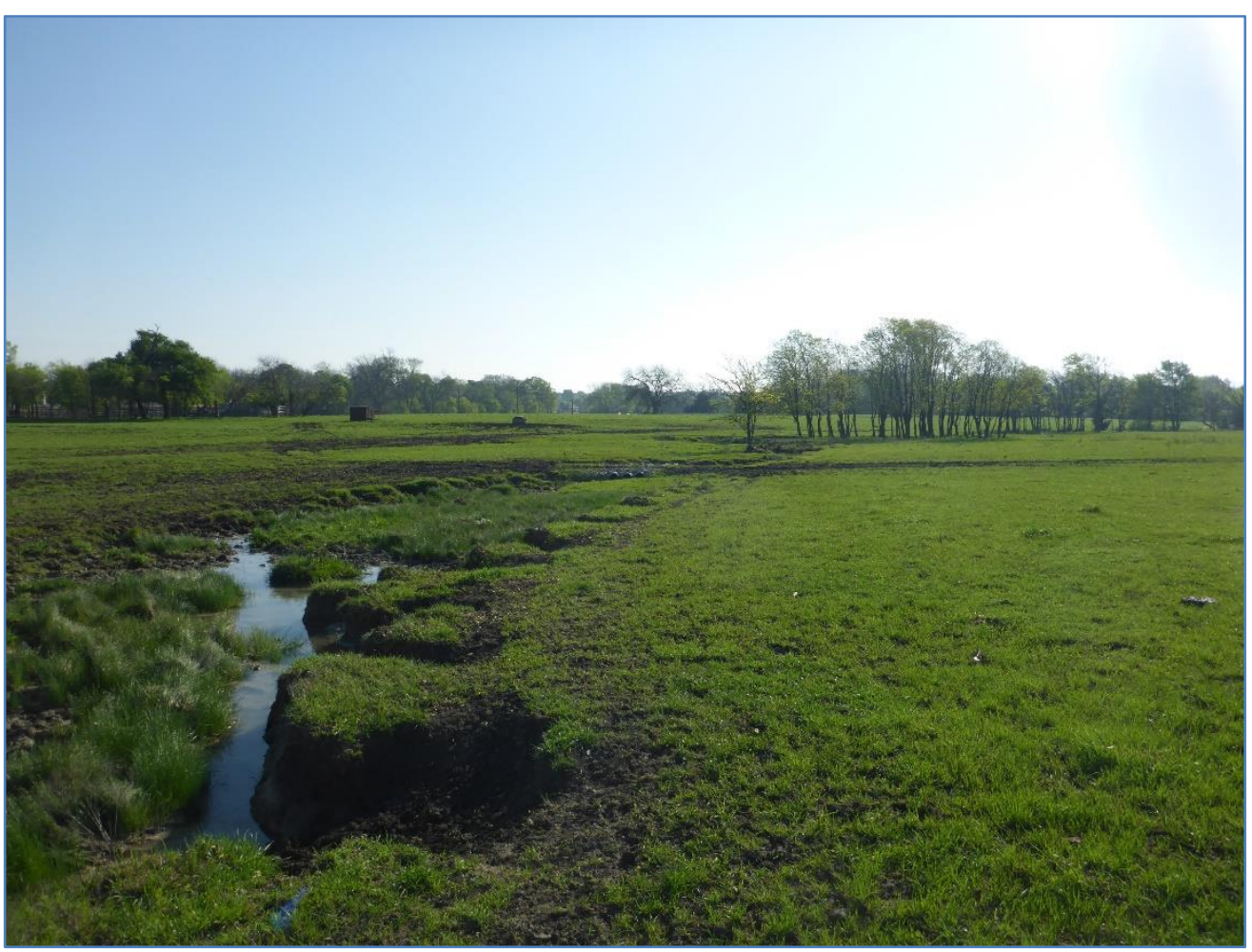

Figure 5. APE from the northwest corner showing active cattle grazing pasture; view east. 


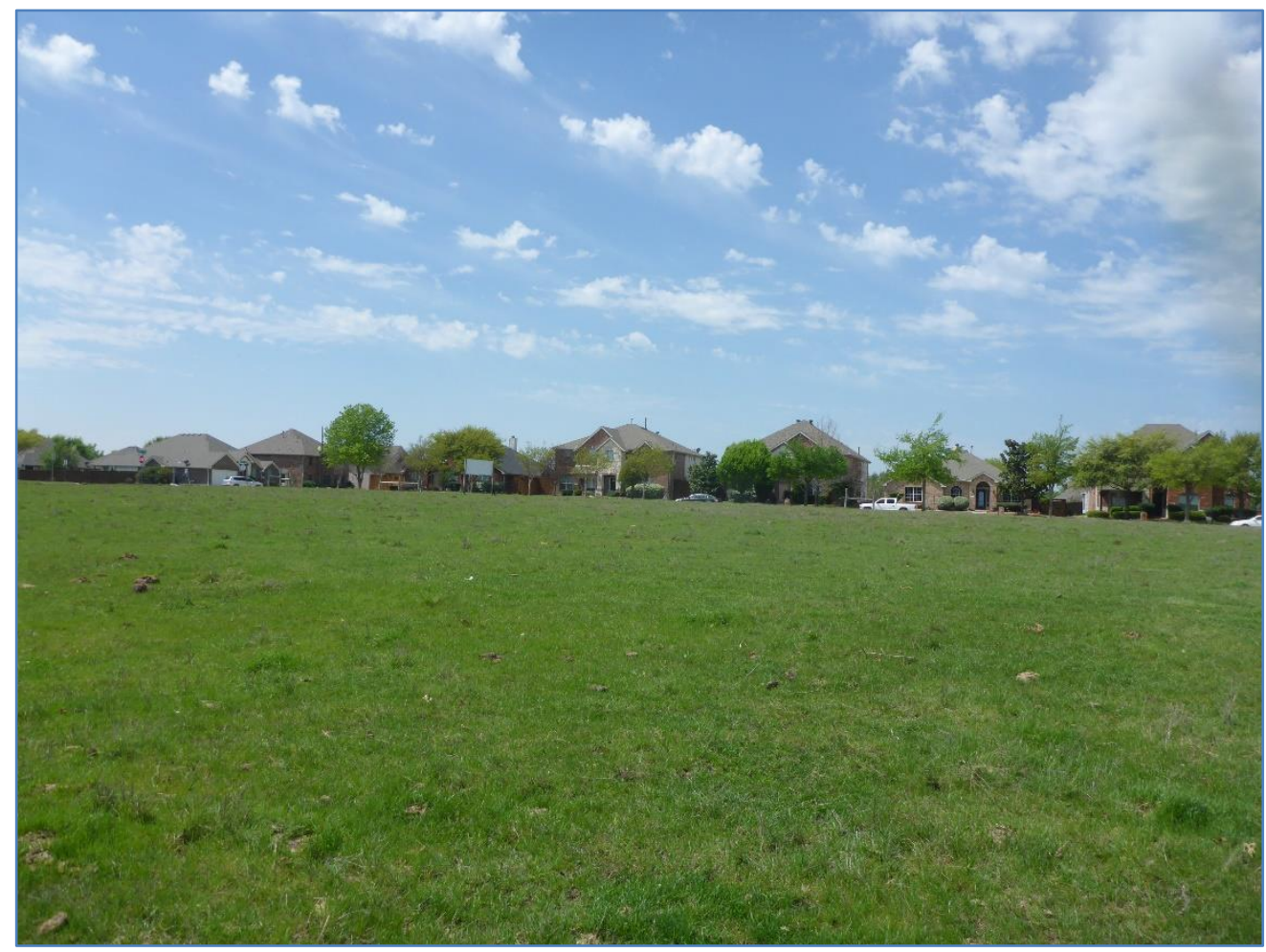

Figure 6. Project area from southwest corner towards Cloverhaven Way; view west.

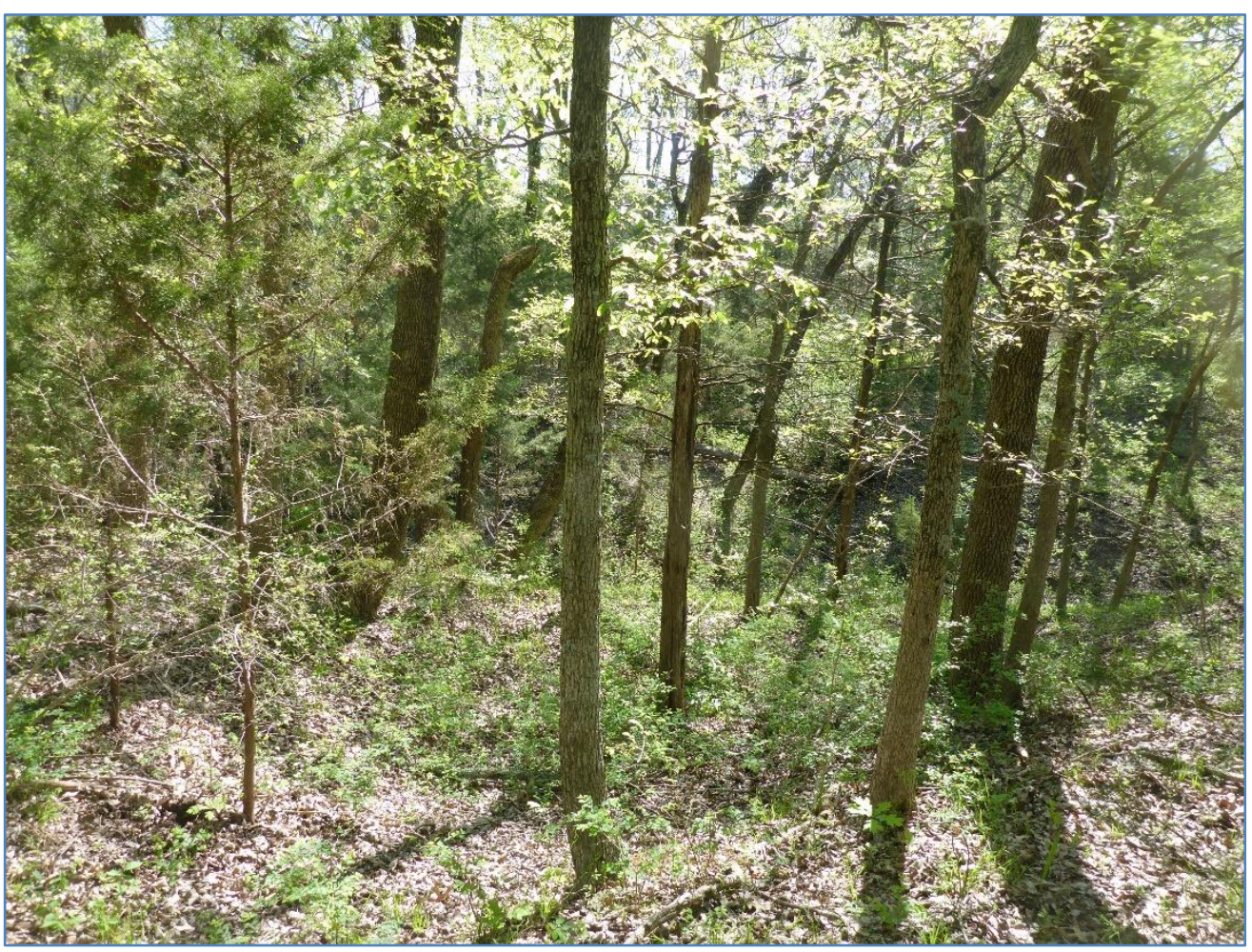

Figure 7. Wooded area near the eastern end of the APE in an eroded area; view east. 


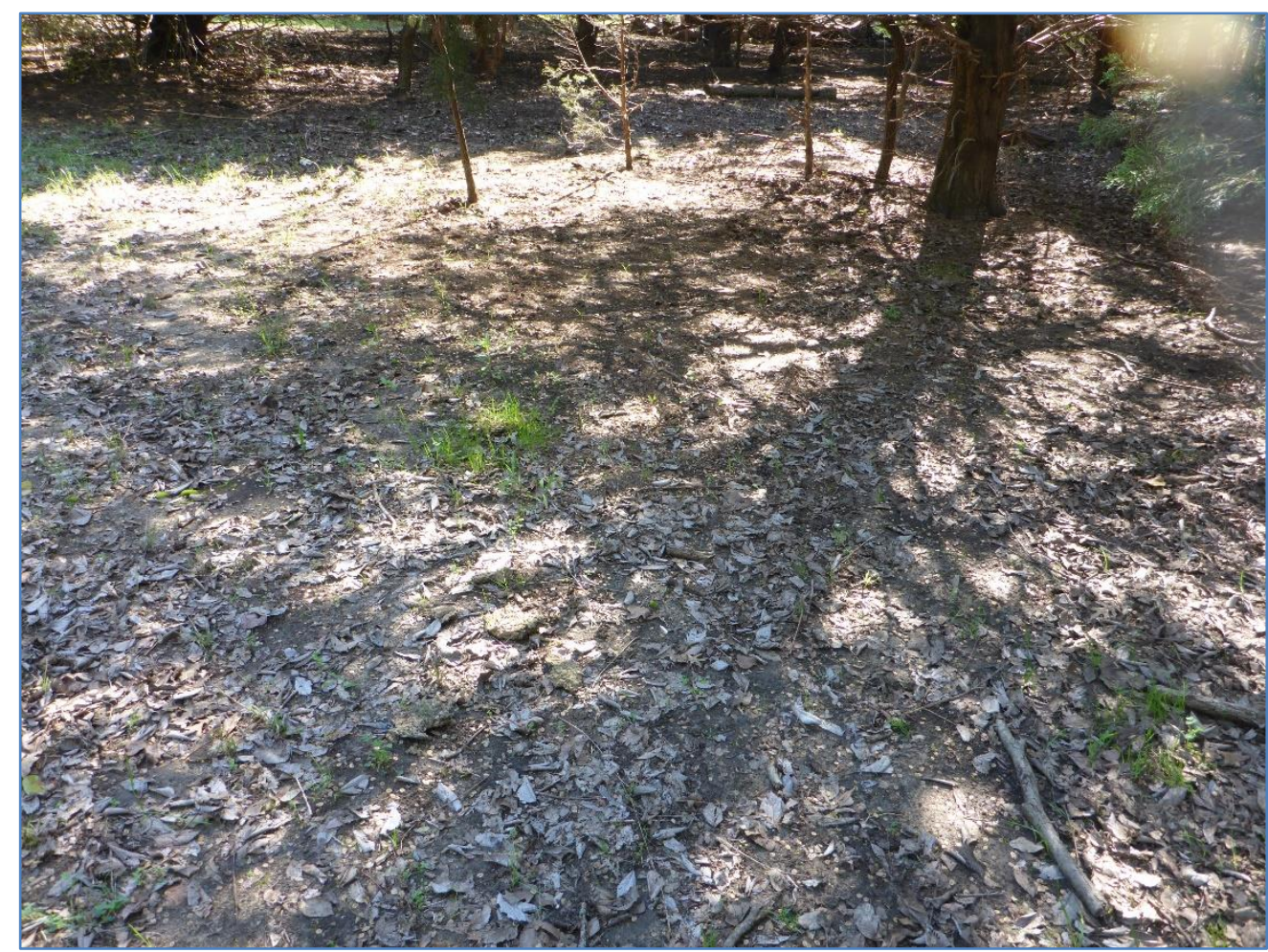

Figure 8. Increased ground visibility near ST BL9 in the wooded section; view east.

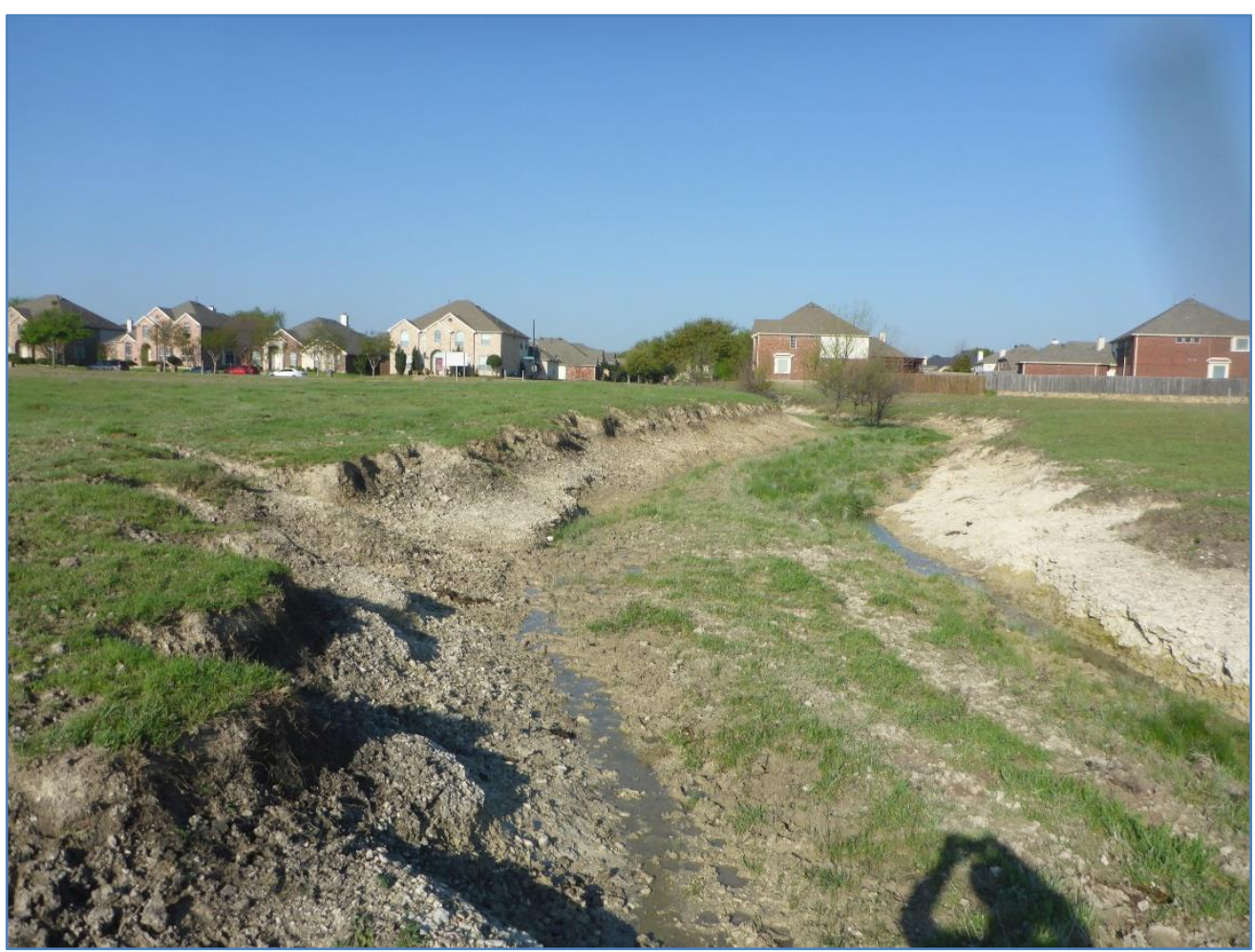

Figure 9. Shallow tributary near ST BL4 showing limestone close to the surface; view west. 


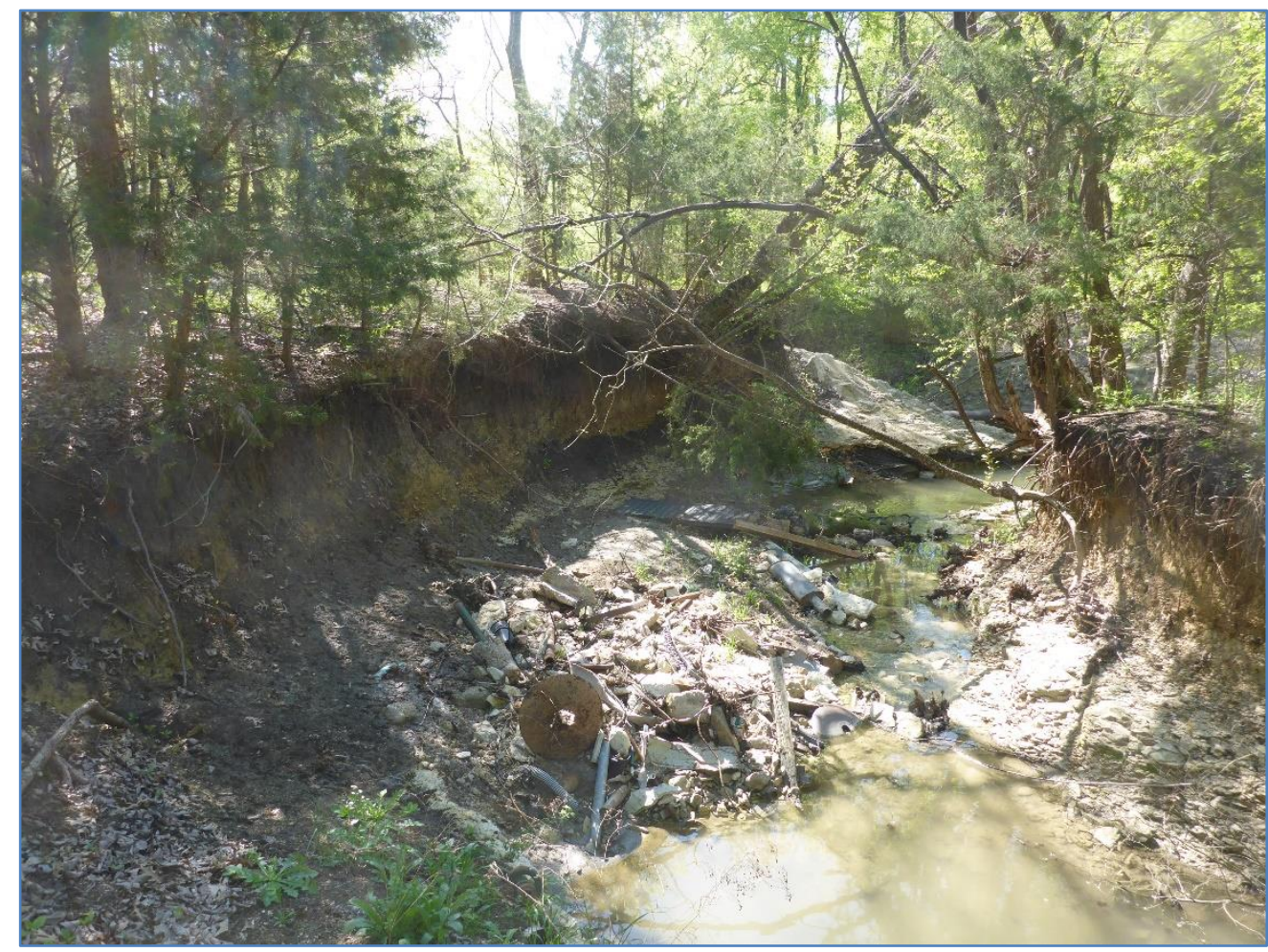

Figure 10. View of wider and deeper tributary near ST BL10; view east.

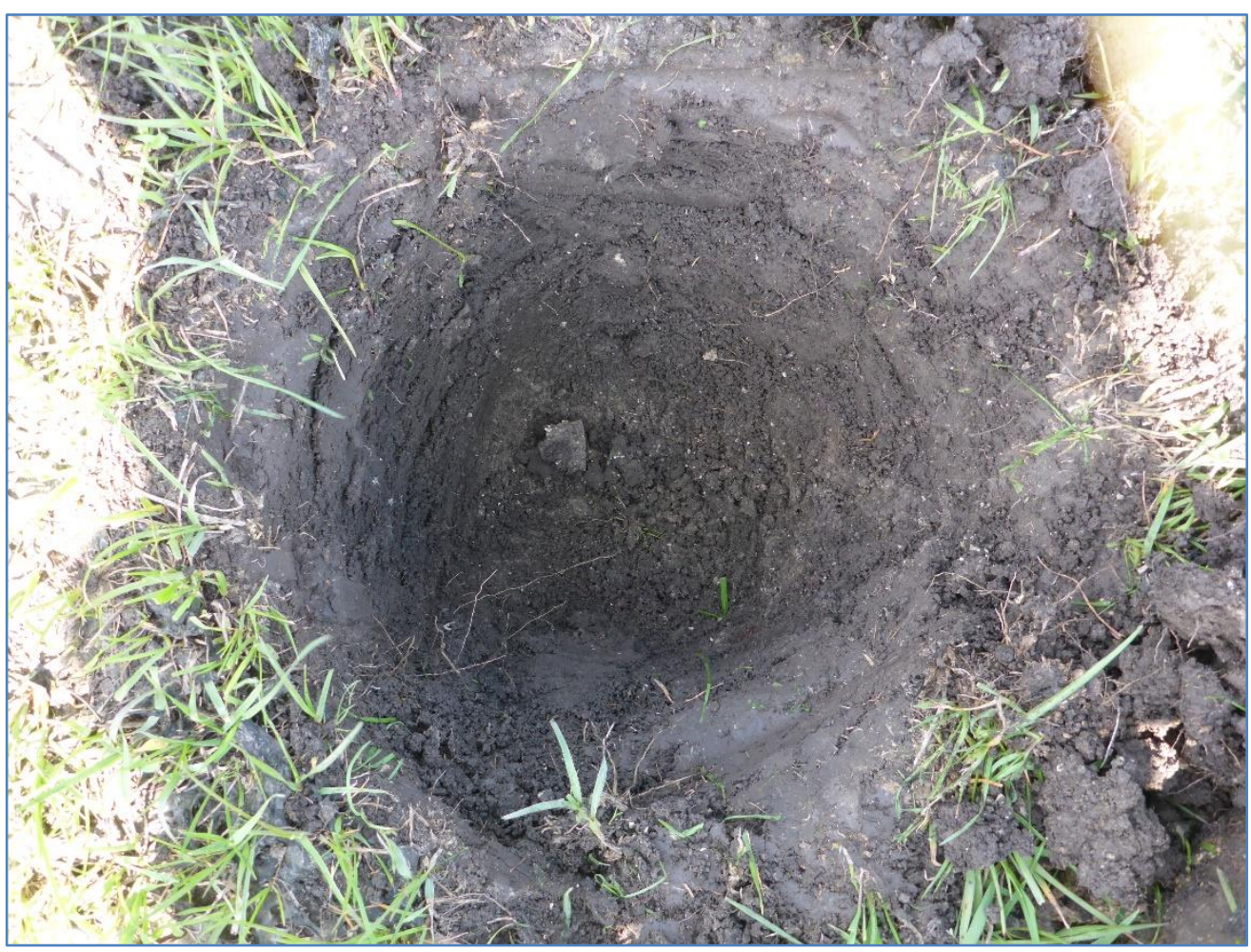

Figure 11 . Shovel test BL15 showing typical stratigraphy; view north and down. 


\begin{tabular}{|c|c|c|c|}
\hline ST \# & $\begin{array}{c}\text { Depth } \\
\text { (cmbs*) }\end{array}$ & Description/Notes & Artifacts \\
\hline BL1 & $0-50$ & Black (10YR 2/1) clay & None \\
\hline \multirow[t]{2}{*}{ BL2 } & $0-10$ & Black (10YR 2/1) clay & None \\
\hline & $10-50$ & Very dark grayish brown clay with $15 \%$ limestone gravels & None \\
\hline \multirow[t]{2}{*}{ BL3 } & $0-5$ & Dark grayish brown (10YR 4/2) clay & None \\
\hline & $5+$ & Limestone gravels & None \\
\hline \multirow[t]{2}{*}{ BL4 } & $0-20$ & Very dark grayish brown (10YR 3/2) clay with $25 \%$ limestone gravels & None \\
\hline & $20-40$ & Dark grayish brown (10YR 4/2) clay with $25 \%$ limestone gravels & None \\
\hline BL5 & $0-50$ & Very dark grayish brown (1OYR $3 / 2$ ) clay with $2 \%$ limestone gravels & None \\
\hline \multirow[t]{2}{*}{ BL6 } & $0-25$ & Very dark grayish brown (10YR $3 / 2$ ) clay with $5 \%$ limestone gravels & None \\
\hline & $25-50$ & Black (10YR $2 / 1$ ) clay with $5 \%$ limestone gravels & None \\
\hline \multirow[t]{2}{*}{ BL7 } & $0-15$ & Very dark grayish brown (10YR 3/2) clay with $10 \%$ limestone gravels & None \\
\hline & $15-40$ & Dark grayish brown (10YR $4 / 2$ ) clay with $20 \%$ limestone gravels & None \\
\hline \multirow[t]{2}{*}{ BL8 } & $0-15$ & Black (10YR 2/1) clay & None \\
\hline & $15-35$ & Very dark grayish brown (10YR 3/2) clay & None \\
\hline \multirow[t]{2}{*}{ BL9 } & $0-10$ & Very dark grayish brown (10YR 3/2) clay & None \\
\hline & $10-30$ & Dark grayish brown (10YR $4 / 2$ ) clay with $40-50 \%$ limestone gravels & None \\
\hline \multirow[t]{2}{*}{ BL10 } & $0-40$ & Black (10YR2/1) clay & None \\
\hline & $40-50$ & Very dark grayish brown (10YR 3/2) clay & None \\
\hline \multirow[t]{2}{*}{ BL1 1} & $0-20$ & Black (10YR 2/1) sandy clay loam & None \\
\hline & $20-40$ & Black (10YR 2/1) clay & None \\
\hline \multirow[t]{2}{*}{ BL1 2} & $0-25$ & Black (10YR 2/1) sandy clay loam & None \\
\hline & $25-40$ & Black (10YR 2/1) clay & None \\
\hline \multirow[t]{2}{*}{ BL13 } & $0-25$ & Black (10YR 2/1) clay & None \\
\hline & $25-40$ & Dark brown (7.5YR 3/2) clay with $25 \%$ pea-sized limestone gravels & None \\
\hline \multirow[t]{2}{*}{ BL1 4} & $0-25$ & Black (10YR 2/1) clay & None \\
\hline & $25-40$ & $\begin{array}{l}\text { Very dark grayish brown (1OYR } 3 / 2 \text { ) clay with } 20 \% \text { degraded } \\
\text { limestone }\end{array}$ & None \\
\hline \multirow[t]{2}{*}{ BL15 } & $0-30$ & Black (10YR 3/1) clay & None \\
\hline & $30-40$ & Dark grayish brown (10YR 4/2) clay with $25 \%$ pea-sized limestone & None \\
\hline \multirow[t]{2}{*}{ BL16 } & $0-30$ & Black (10YR 3/1) clay & None \\
\hline & $30-40$ & Dark grayish brown (10YR 4/2) clay with $5 \%$ pea-sized limestone & None \\
\hline BL17 & $0-50$ & Very dark grayish brown (10YR 3/2) clay & None \\
\hline BL1 8 & $0-50$ & Black (10YR 2/1) clay & None \\
\hline \multirow[t]{2}{*}{ BL19 } & $0-30$ & Black (10YR 2/1) clay & None \\
\hline & $30-40$ & Very dark grayish brown (10YR 3/2) clay & None \\
\hline
\end{tabular}

Disturbances were observed throughout the project $A P E$, but these were more concentrated closer to the eastern boundary. The western half of the APE was minimally disturbed from extended cattle grazing and erosion. However, more substantial disturbance included a manmade berm, running parallel with Cloverhaven Way containing old concrete chunks and various gravels (Figure 12). The majority of the disturbance was located near the eastern boundary. A two-lane paved walking/biking path runs mostly 
parallel with Cottonwood Creek in a cleared section on the western edge and between two wooded areas. The area had been previously surveyed (see Stone 2017) not requiring any additional shovel testing immediately adjacent to the path (Figure 13). The northeast corner of the project APE was disturbed from ongoing construction of a NTMWD maintenance facility and a buried sewer pipeline running east/west (Figures 14 and 15). Immediately south of the maintenance facility travelling north/south on the west bank of Cottonwood Creek was another sewer pipeline corridor extending the length of the APE to the southeast corner (Figure 16). For this reason, the shovel tests along the west bank of Cottonwood Creek were moved slightly west into a more undisturbed wooded area.

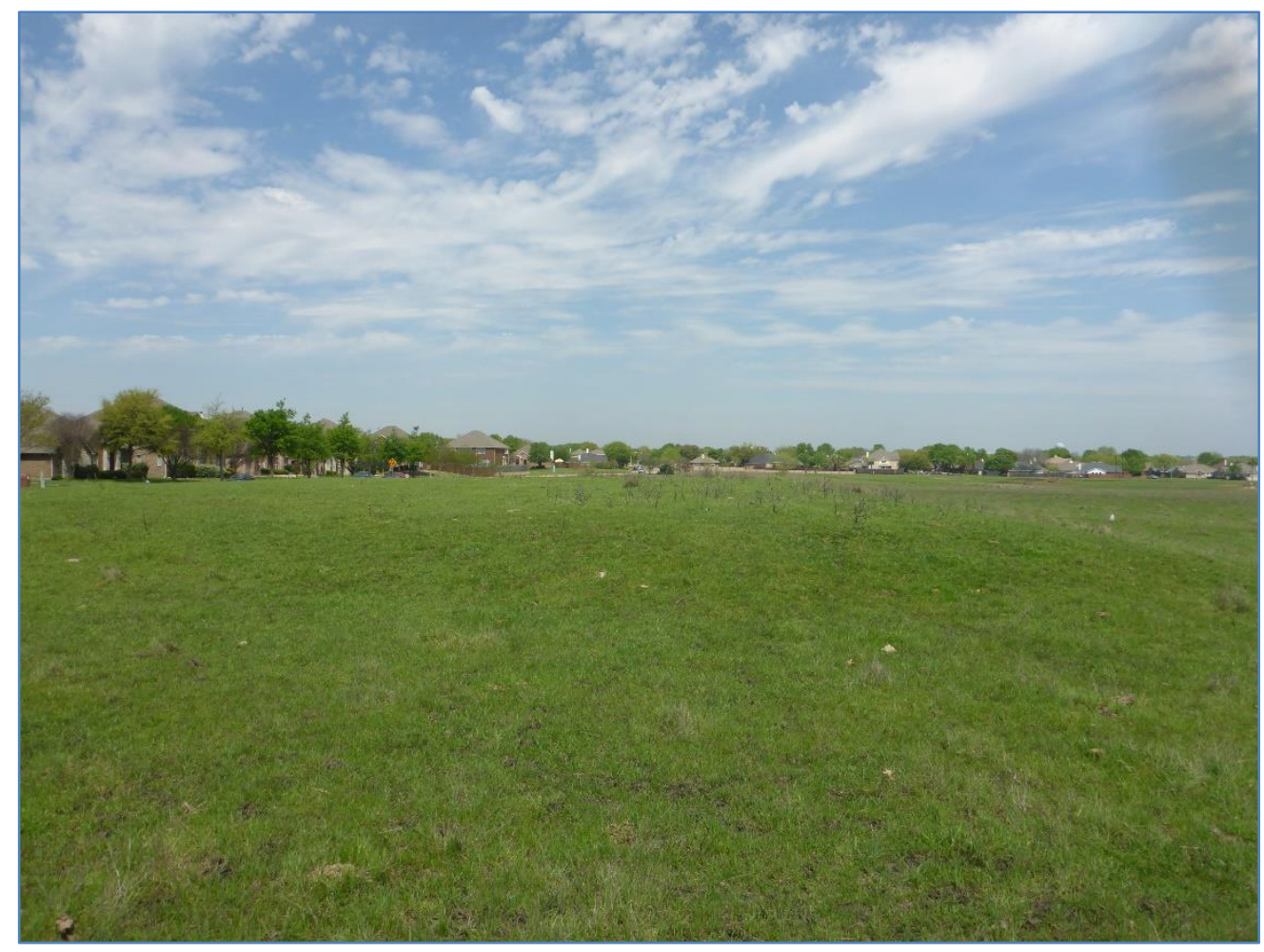

Figure 12. Disturbed berm parallel to Cloverhaven Way running north/south; view north. 


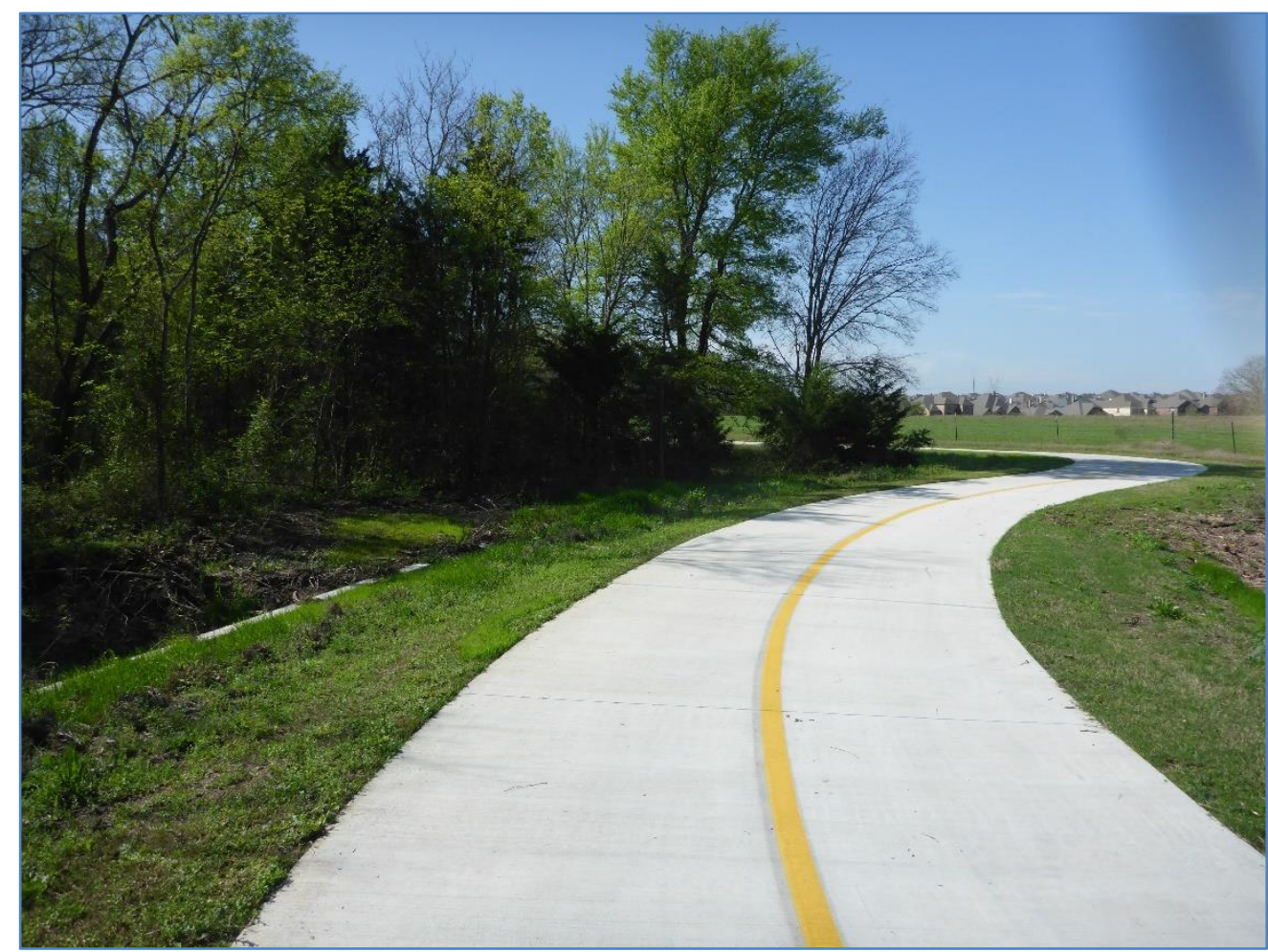

Figure 13. Two-lane paved hike and bike path along eastern boundary; view south.

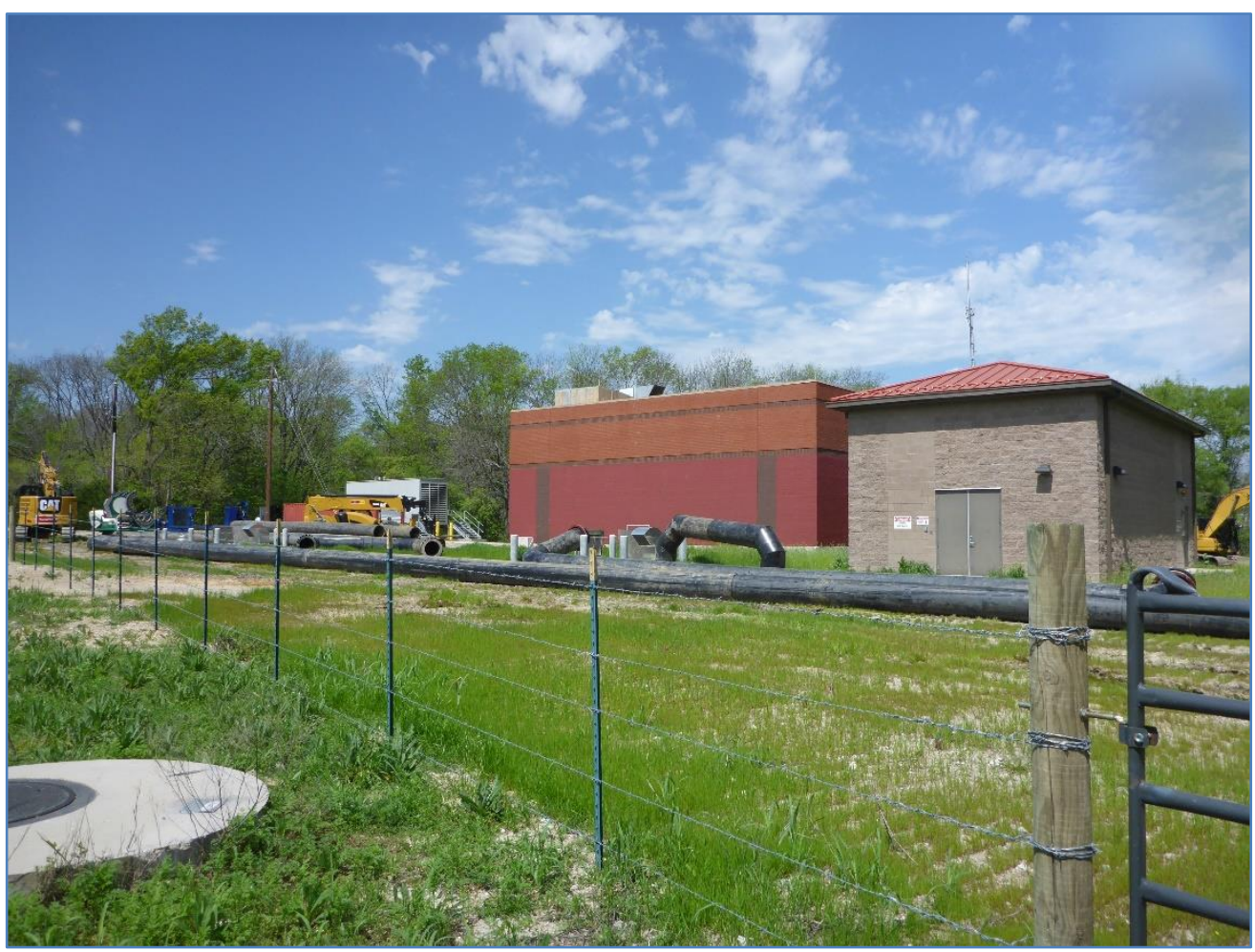

Figure 14. NTMWD maintenance facility construction disturbance in the northeast corner of APE; view northwest. 


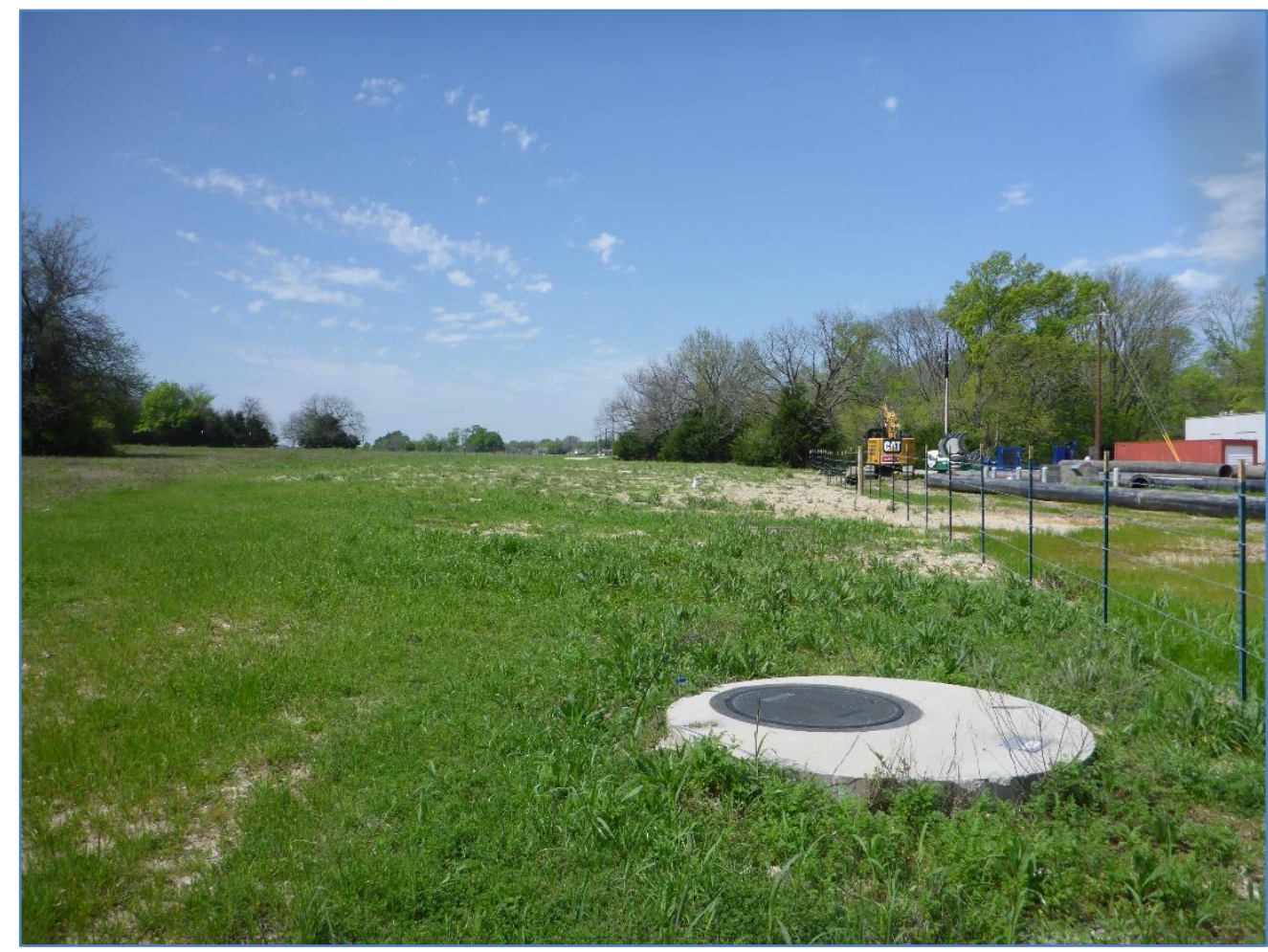

Figure 15. Sewer line disturbance at the northeast corner of $A P E$; view west.

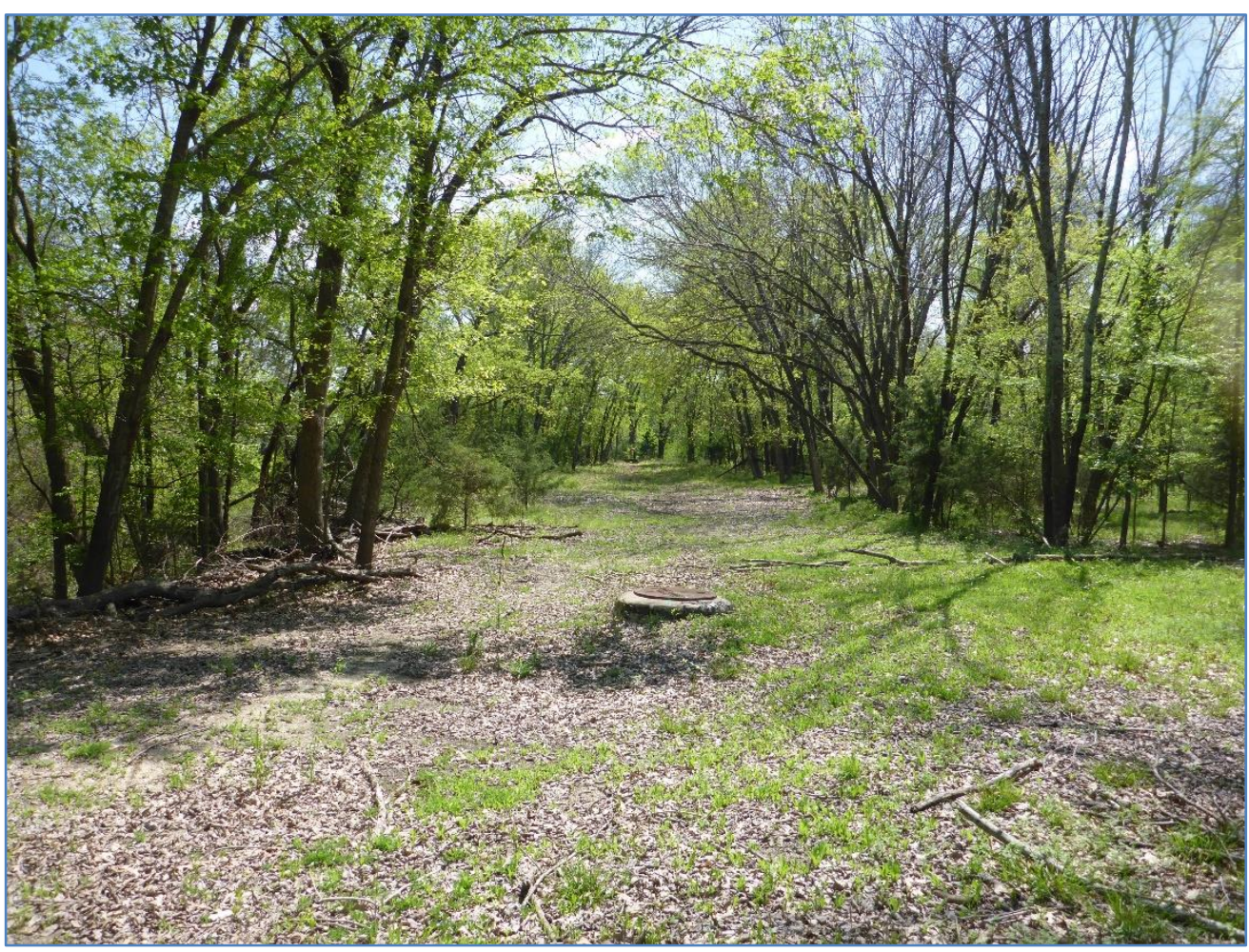

Figure 16. Sewer line corridor disturbance on the west bank of Cottonwood Creek; view south. 


\section{SUMMARY AND RECOMMENDATIONS}

The results from the cultural resources survey of the 103-ac (42-ha) project parcel yielded no cultural material. In all, 19 STs were excavated primarily along the higher potential areas associated with a tributary of Cottonwood Creek and Cottonwood Creek with clay or subsoil mottled clay encountered. The remaining areas of the project APE were pedestrian surveyed with two additional shovel tests placed on the northwest and southwest corners. All 19 STs were negative for cultural material, and no cultural material was observed on the ground surface.

\section{Recommendation}

Due to the past agricultural endeavors, cattle grazing practices in the past and present, lack of artifacts in any of the 19 STs or on the ground surface, and various disturbances observed, no additional information about the prehistoric- or historic-age history of the project parcel in Plano or North Central Texas was ascertained. Therefore, it is recommended that no additional archeological investigations are warranted, and the City of Plano proceed with their plans for the construction of the proposed athletic complex. If any unanticipated cultural materials or deposits are found at any stage of clearing, preparation, or construction, the work should cease and THC personnel should be immediately notified.

No artifacts were collected during the survey. However, all notes, photographs, administrative documents, and other pertinent project data generated from this investigation will be housed at CAS, where they will be made permanently available to future researchers per 13 TAC 26.16-17. 


\section{REFERENCES}

Blum, M. D., J. T. Abbott, and S. Valastro

1992 Evolution of Landscapes on the Double Mountain Fork of the Brazos River, West Texas: Implications for Preservation and Visibility of the Archaeological Record. Geoarchaeology 7(4):339-370.

Campbell, R. B.

2003 Gone to Texas: A History of the Lone Star State. Oxford University Press, New York.

Farmer, R. W.

2011 From Blackland Prairie to Blacktop: A History of Collin County. San Antonio, TEX: Historical Publishing Network.

Ferring, C. R.

1989 The Aubrey Clovis Site: A Paleoindian Locality in the Upper Trinity River Basin, Texas. Current Research in the Pleistocene 6:9-11.

2001 The Archaeology and Paleoecology of the Aubrey Clovis Site (41DN479), Denton County, Texas. Report prepared for U.S. Army Corps of Engineers, Fort Worth District. Center for Environmental Archaeology, Department of Geography, University of North Texas, Denton.

Ferring, C. R., and B. C. Yates (with contributions by H. Gill-King and K. Brown)

1997 Holocene Geoarcheology and Prehistory of the Ray Roberts Lake Area, North Central Texas. Report prepared for U.S. Army Corps of Engineers, Fort Worth District. Institute of Applied Sciences, University of North Texas, Denton.

Goodmaster, C.

201041 COL215 Texas Archeological Site Form. Available at https://atlas.thc.texas.gov/ Account/Login?Length=5. Password protected. Accessed 10 March 2020.

Google Earth Pro ${ }^{\mathrm{TM}}$

2020 Historic Aerial Imagery of Plano and Allen, Texas viewed through Google Earth ${ }^{\text {TM }}$. Google. Available at https://www.google.com/earth/. Accessed 5 March 2020.

Griffith, G. E., S. A. Bryce, J. M. Omernik, J. A. Comstock, A. C. Rogers, B. Harrison, S. L. Hatch, and D. Bezanson

2010 Ecoregions of Texas. Bureau of Economic Geology. Reproduced from the U.S. Geological Survey 2004 Map Version. Available at https://editors.eol.org/eoearth/wiki/ Ecoregions_of_Texas_(EPA). Accessed 5 March 2020.

Hofman, J. L., R. L. Brooks, J. S. Hays, D. W. Owsley, R. L. Jantz, M. K. Marks, and M. H. Manhein

1989 From Clovis to Comanchero: Archeological Overview of the Southern Great Plain. Arkansas Archeological Research Series No. 35. Arkansas Archeological Survey, Fayetteville. 
Holliday, V. T.

2004 Soils in Archaeological Research. Oxford University Press, New York.

Jurgens, C. J.

199241 COL89 Texas Archeological Site Form. Available at https://atlas.thc.texas.gov/ Account/Login?Length=5. Password protected. Accessed 10 March 2020.

Minor, D.

2010 Collin County. In The Handbook of Texas Online. Texas State Historical Association. Available at http://www.tshaonline.org/handbook/online/articles/hccl6. Uploaded on June 15, 2010. Accessed 5 March 2020.

National Environmental Title Research (NETR)

2020 Historic Aerials Database, Plano, Texas. Nationwide Environmental Title Research. Available at http://www.historicaerials.com. Accessed 5 March 2020.

Omernik, J. M. and G. E. Griffith

2013 Ecoregions of Texas (EPA). The Encyclopedia of Earth. (Bureau of Economic Geology Ecoregions of Texas Map date 2010 in article). Article updated 27 March 2013. Available at https://editors.eol.org/eoearth/wiki/Ecoregions_of_Texas_(EPA). Accessed 5 March 2020.

Perttula, T. K.

2004 An Introduction to Texas Prehistoric Archeology. In The Prehistory of Texas, edited by T. K. Perttula, pp. 5-14. Texas A\&M University Press, College Station.

Peter, D. E., and D. E. McGregor (editors)

1988 Late Holocene Prehistory of the Mountain Creek Drainage. Joe Pool Lake Archaeological Project, vol. I. Archaeology Research Program, Southern Methodist University, Dallas.

Prikryl, D. J.

1990 Lower Elm Fork Prehistory: A Redefinition of Cultural Concepts and Chronologies along the Trinity River, North Central Texas. Report 37. Office of the State Archeologist, Texas Historical Commission, Austin.

Soil Survey Staff, U.S. Department of Agriculture, Natural Resources Conservation Service (NRCS) 2020 Soil Survey Geographic (SSURGO) Database for Collin County, Texas. Available at http://casoilresource.lawr.ucdavis.edu/soilweb/. Accessed 5 March 2020.

Spatial Climate Analysis Service (SCAS)

2000 Average Annual Precipitation for Texas. PRISM Climate Group at Oregon State University. Available at http://www.prism.oregonstate.edu/gallery/view.php?state=TX_E. Accessed 5 March 2020.

Stephenson, R. L.

1970 Archeological Investigations in the Whitney Reservoir Area, Central Texas. Bulletin of the Texas Archeological Society 41:37-277. 
Stone, $\mathrm{K}$.

2017 Archeological Survey Report: CS (Cottonwood Creek Trail Extension) From Oak Point Park and Nature Preserve to Chaparral Road, CSJ: 0918-24-2 1 4, Collin County, Texas.

Integrated Environmental Solutions, McKinney.

Texas General Land Office

n.d. "Peters Colony Records" Finding Aid Summary. Available at http://www.glo.texas.gov/ history/archives/collections/index.html\#item/153. Accessed 5 March 2020.

Texas Historical Commission (THC)

2020 Texas Archeological Sites Atlas. Texas Archeological Research Laboratory and the Texas Historical Commission. Available at https://atlas.thc.texas.gov/Account/Login?Length=5. Password protected. Accessed 5 March 2020.

Tipton, J.

2020 "Leach-Thomas Cemetery". Find A Grave. Available at https://www.findagrave.com/ cemetery/2145178/leach-thomas-cemetery. Accessed 10 March 2020.

United States Geological Survey (USGS)

2020a Pocket Texas Geology. United States Geological Survey. Available at https://txpub.usgs.gov/txgeology/. Accessed 5 March 2020.

2020b USGS Historical Topographic Map Explorer. United States Geological Survey. Available at http://historicalmaps.arcgis.com/usgs/. Accessed 5 March 2020.

Wade, Harry E.

2010 Peters Colony. In The Handbook of Texas Online. Texas State Historical Association. Available at http://www.tshaonline.org/handbook/online/articles/vep02. Uploaded on June 15, 2010. Accessed 5 March 2020.

Yates, B. C., and C. R. Ferring (editors)

1986 An Assessment of the Cultural Resources in the Trinity River Basin, Dallas, Tarrant, and Denton Counties, Texas. Institute of Applied Sciences, North Texas State University, Denton. Submitted to the U.S. Army Corps of Engineers, Fort Worth District. 


\section{APPENDIX A}

Regulatory Correspondence 
From:

Sent:

To:

Subject:
Chris Dayton

Friday, May 08, 2020 6:17 PM

Missi Green

Fwd: Project Review: 202011270

Sent from my Sprint Samsung Galaxy S10.

From: noreply@thc.state.tx.us <noreply@thc.state.tx.us>

Sent: Friday, May 8, 2020, 4:52 PM

To: Chris Dayton; reviews@thc.state.tx.us

Subject: Project Review: 202011270

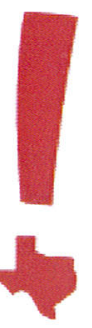

\section{TEXAS HISTORICAL COMMISSION \\ real places telling real stories}

Re: Project Review under Section 106 of the National Historic Preservation Act and/or the Antiquities Code of Texas Permit 9334

\section{THC Tracking \#202011270}

Moore Park Athletic Complex

Chaparral Road

Plano,TX 75074

Dear Chris Dayton:

Thank you for your submittal regarding the above-referenced project. This response represents the comments of the Executive Director of the Texas Historical Commission (THC), pursuant to review under the Antiquities Code of Texas.

The review staff led by Arlo McKee and Caitlin Brashear has completed its review and has made the following determinations based on the information submitted for review:

\section{Above-Ground Resources}

- No further review of potential effects to above-ground historic resources is required under the Antiquities Code of Texas. However, should this project ultimately include any federal involvement, additional consultation with THC/SHPO under Section 106 of the National Historic Preservation Act will be required.

\section{Archeology Comments}

- No effect on archeological sites. However, if buried cultural materials are encountered during construction or disturbance activities, work should cease in the immediate area; work can continue where no cultural materials are present. Please contact the THC's Archeology Division at 512-463-6096 to consult on further actions that may be necessary to protect the cultural remains.

- No sites recorded. 
- Draft report acceptable. Please submit another copy as a final report along with shapefiles showing the area where the archeological work was conducted. Shapefiles should be submitted electronically to

Archeological_projects@thc.texas.gov.

We look forward to further consultation with your office and hope to maintain a partnership that will foster effective historic preservation. Thank you for your cooperation in this review process, and for your efforts to preserve the irreplaceable heritage of Texas. If you have any questions concerning our review or if we can be of further assistance, please email the following reviewers: Arlo.McKee@thc.texas.gov, caitlin.brashear@thc.texas.gov

This response has been sent through the electronic THC review and compliance system (eTRAC). Submitting your project via eTRAC eliminates mailing delays and allows you to check the status of the review, receive an electronic response, and generate reports on your submissions. For more information, visit http://thc.texas.gov/etrac-system.

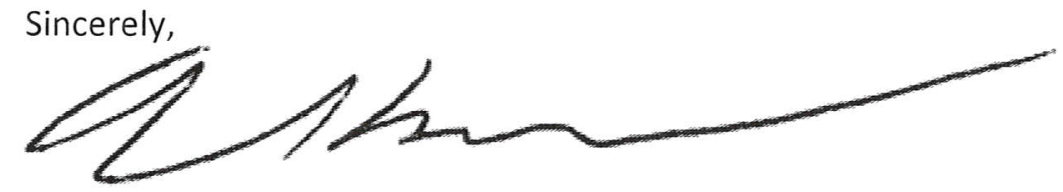

For Mark Wolfe, State Historic Preservation Officer

Executive Director, Texas Historical Commission

Please do not respond to this email. 